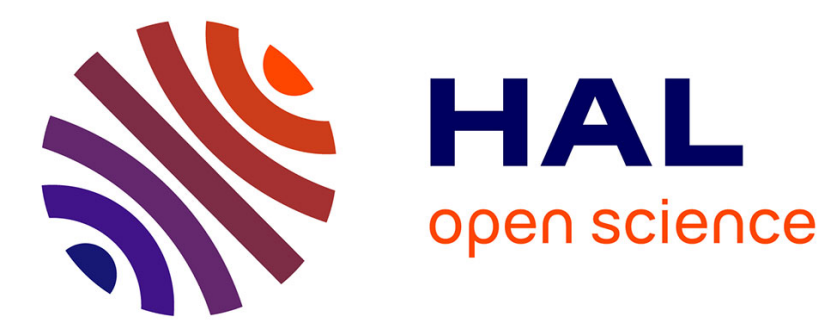

\title{
Upper ocean temperature and salinity sections in the South Atlantic in 1911
}

Gilles Reverdin

\section{To cite this version:}

Gilles Reverdin. Upper ocean temperature and salinity sections in the South Atlantic in 1911. Journal of Geophysical Research, 1996, 101, pp.6361-6376. 10.1029/95JC03374 . hal-00772213

\section{HAL Id: hal-00772213 \\ https://hal.science/hal-00772213}

Submitted on 6 Feb 2021

HAL is a multi-disciplinary open access archive for the deposit and dissemination of scientific research documents, whether they are published or not. The documents may come from teaching and research institutions in France or abroad, or from public or private research centers.
L'archive ouverte pluridisciplinaire HAL, est destinée au dépôt et à la diffusion de documents scientifiques de niveau recherche, publiés ou non, émanant des établissements d'enseignement et de recherche français ou étrangers, des laboratoires publics ou privés. 


\title{
Upper ocean temperature and salinity sections in the South Atlantic in 1911
}

\author{
Gilles Reverdin 1 \\ Lamont-Doherty Earth Observatory, Columbia University, Palisades, New York
}

\begin{abstract}
Hydrographic cruises conducted in July-October 1911 by the "Fram," the "Deutschland," and the "Möwe" and in January-February 1911 by the "Stephan" provide a survey of the upper South Atlantic subtropical gyre during the cold season and of the equatorial Atlantic. The data accuracy is not as high as in more recent surveys, in particular, the depth of the measurement is not known precisely: the Fram temperature is only good to within $0: 10^{\circ} \mathrm{C}$ accuracy and salinity to within 0.02 . The South Atlantic cold season stations often present a 100 -m or thicker surface mixed layer overlaying a thermocline with maximum vertical gradient increasing from the southwest to the northeast. A layer of minimum vertical temperature gradient of $0.01^{\circ} \mathrm{C} \mathrm{m}^{-1}$ at a temperature close to $13^{\circ} \mathrm{C}$ is embedded in the upper thermocline between $40^{\circ} \mathrm{W}$ and $20^{\circ} \mathrm{W}$ on the southern section of the $\mathrm{Fram}\left(30^{\circ} \mathrm{S}\right.$ to $\left.35^{\circ} \mathrm{S}\right)$. This defines a mode water at a density (26.60) close to the surface density of deep mixed layers offshore of the Brazil current found between $34^{\circ} \mathrm{S}$ and $39^{\circ} 21^{\prime} \mathrm{S}$ but which is warmer and saltier $\left(14.9^{\circ} \mathrm{C}, 35.70\right)$. The $1911 \mathrm{~T}-\mathrm{S}$ characteristics in the subtropical South Atlantic thermocline present little zonal variations, with the warmest, saltiest water on isopycnal surfaces found in the southwestern portion of the survey and the coldest, freshest waters near Namibia. The 1911 South Atlantic surface waters are much colder than the average situation in recent decades (average of $-0.82^{\circ} \mathrm{C}$ ) and are a little fresher $(-0.04)$ than the hydrographic climatology for that season. In the subtropical gyre, the isopycnals were probably deeper in 1911 than in 1926, except in the southwestern corner, and the slope of the T-S relationship was larger in 1911 than in 1925-1926, with warmer and saltier waters in the upper thermocline (above $\gamma=26.6-26.4$ ) and fresher and cooler waters in the lower thermocline. On the other hand, T-S characteristics in the equatorial thermocline are comparable in 1911 and 1926. Both surveys present water masses which are colder and fresher on isopycnal surfaces than the surveys in the 1960s.
\end{abstract}

\section{Introduction}

Water masses and the geostrophic circulation in the South Atlantic have been recently investigated from hydrographic sections scattered over many years and seasons by Reid [1989] and Peterson and Stramma [1991]. On a typical isopycnal of the thermocline $(\gamma=26.72)$ [cf. Reid, 1989, Figure 8], the South Atlantic subtropical gyre appears as an area of weak water mass property gradients sandwiched between more salty equatorial water to the north and fresher water to the south and southeast. According to Gordon et al.'s [1992] geostrophic analysis of the southeastern sector of the subtropical gyre, the surface flow is eastward at the surface south of $30^{\circ} \mathrm{S}$, whereas the flow at $500 \mathrm{~m}$ is probably eastward only south of $35^{\circ} \mathrm{S}$. The eastward surface circulation south of $30^{\circ} \mathrm{S}$ in the central southern Atlantic is also supported by the First Global Atmospheric Research Program Global Experiment (FGGE) drifters [Piola et al., 1987]. The thermocline flow is to the west or northwest north of this boundary [Levitus, 1982; Reid, 1989; Stramma and Peterson,

\footnotetext{
${ }^{1}$ Now at Unité Mixte de Recherche 39, Groupe de Recherche en Géodésie Spatiale, Toulouse, France.

Copyright 1996 by the American Geophysical Union.

Paper number 95JC03374.

0148-0227/96/95JC-03374\$05.00
}

1990], in particular, close to the transition with the equatorial water. Large eddies embedded in this flow carry water from the Agulhas current into the Atlantic subtropical gyre [Gordon and Haxby, 1990]. Upon impeding on the continental slope of South America, part of the water flows southward in the Brazil Current, a transport which quickly increases southward until the separation at the Brazil-Malvinas confluence [Stramma, 1989]. However, a significant portion of the thermocline water flows toward the equatorial area along Brazil (at least $10 \times 10^{6} \mathrm{~m}^{3} \mathrm{~s}^{-1}$ according to Reverdin et al. [1993] and Stramma et al. [1995]. It is then transformed by horizontal mixing with a small portion of North Atlantic subtropical water and possibly by vertical mixing processes, though, to a large extent, it still has characteristics of the southern hemisphere. Most of the water in the upper thermocline is eventually entrained in the surface layer. This provides a fairly coherent view of the circulation, although one can question how much unresolved seasonal or interannual variability affects our understanding of the South Atlantic and, in particular, of the ventilation of the upper ocean subsurface waters.

Investigating the past upper ocean variability is an important step in understanding the role the ocean plays in the climate variability of the Earth. The sea surface conditions have been documented from ship reports from which the seasonal cycle and interannual variability of sea surface temperature (SST) can be inferred in a large portion of the Atlantic Ocean since the first decades of this century. For 
instance, Bottomley et al. [1990] indicate that the decade 1906-1915 is the coldest reported, both in the northern and in the southern Atlantic Ocean. In the subtropical South Atlantic the departure of SST in this decade from the average seasonal average for 1951-1980 almost everywhere exceeds $-0.5^{\circ} \mathrm{C}$. Surface salinity seasonal cycle has also been deduced from station data and surface samples collected from ships-ofopportunity both in the northern Atlantic [Smed, 1940] and in the southern Atlantic [Krauss, 1962]. In the northern North Atlantic the data are often sufficient to retrieve decadal variability, but this is not the case in the subtropical North Atlantic, nor in the equatorial and South Atlantic. The surface temperature measurements and surface salinity data sets are subject to various errors [Parker and Folland, 1991; Reverdin et al., 1994] which can sometimes only be guessed at and whose approximate removal casts some uncertainty upon the analyses.

The approach adopted here for assessing past variability is to investigate hydrographic data. The subsurface data are sparser but often more accurate than the surface ones, and the subsurface variability has often been observed to have a red spectrum, with decadal variability dominating the interannual to interseasonal band [Ellett, 1982; Joyce and Robbins, 1996; Jenkins, 1982; Archer et al., 1994]. These examples are taken in the North Atlantic or the South Pacific Oceans, but it is reasonable to expect that this also holds for the southern subtropics and midlatitudes. Near the equator, higherfrequency variability is observed near the surface and in the thermocline depth. The equatorial thermocline water mass (i.e., the T-S characteristics) should not be affected by this variability related to local air-sea interaction or vertical displacements of the thermocline, because these waters originate from the subtropics and have been isolated from the surface for more than 10 years [Warner and Weiss, 1992; Doney and Bullister, 1992; Reverdin et al., 1993]. We therefore expect that isolated ancient sections will contribute to our understanding of the low-frequency variability of the thermocline water masses.

Exploratory investigation of the South Atlantic was initiated by cruises scattered over many years from the "Challenger" and "Gazelle" expeditions in 1873-1876 to the "Valdivia," "Gauss," "Antarctic," and "Scotia" expeditions around the turn of the century. Schott [1902] provides a synthesis of these early temperatures, in particular, for deep and intermediate layers, with possible systematic biases of the order of $0.1^{\circ} \mathrm{C}$. The salinity measurements of these expeditions often do not have the accuracy of a few 0.01 (salinity is expressed in practical salinity units) required to define well the intermediate and thermocline water masses and to provide a reference against which the more recent data can be compared [Möller, 1926; Wüst, 1935]. The "Planet" 19061907 expedition introduced a new era with an improved accuracy for salinity of a few 0.01 and with measurements of dissolved oxygen concentration, but the few stations with coarse vertical resolution collected in the South Atlantic during this expedition are not sufficient to provide an adequate reference.

The 1910-1911 cruises (Figure 1) provide the first fairly comprehensive survey of the hydrography of the Atlantic Ocean from north to south, which relied on techniques for conducting station casts and measuring water temperature and salinity developed around the turn of the century [HellandHansen and Nansen, 1909]. This paper discusses primarily the hydrographic stations collected in 1911 in the equatorial and subtropical South Atlantic Ocean (Figures la and 1b). The stations collected mostly in 1910 in the northern North Atlantic have been discussed by Dickson et al. [1984], who indicate that the water masses in the upper ocean were fresher and colder than in the surveys of the late 1950s which corresponded to a warm period at the surface.

There is not much recent data against which to compare the 1911 sections in the subtropical South Atlantic Ocean, especially when one restricts the comparison to sections of the same season (cold season). The most extensive were the $27^{\circ} \mathrm{S}-30^{\circ} \mathrm{S}$ section in July-August 1925 and the $21^{\circ} \mathrm{S}-24^{\circ} \mathrm{S}$ section in July-August 1926 from the Meteor expedition [Wïst, 1935; Defant, 1936] (Figure 1c), as well as the $24^{\circ} \mathrm{S}$ "Crawford" section in October 1958 and the Ajax section in October 1983 close to the date line. Even temperature profiles from bathythermographs are uncommon during the cold season over most of the interior subtropical gyre: for example, between $15^{\circ} \mathrm{S}$ and $20^{\circ} \mathrm{S}, 30^{\circ} \mathrm{W}$ and $10^{\circ} \mathrm{E}$, only 42 temperature profiles were used in the July-August climatology of Lamb [1984], and the coverage is even worse farther south, although the situation has recently improved with expendable bathythermographs launched mainly since 1982. This lack of data results in a fairly uncertain climatology of the cold

$01-081911$

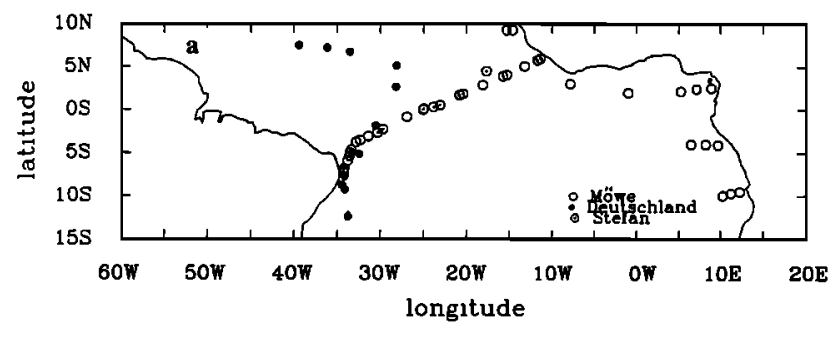

06-10 1911 survey

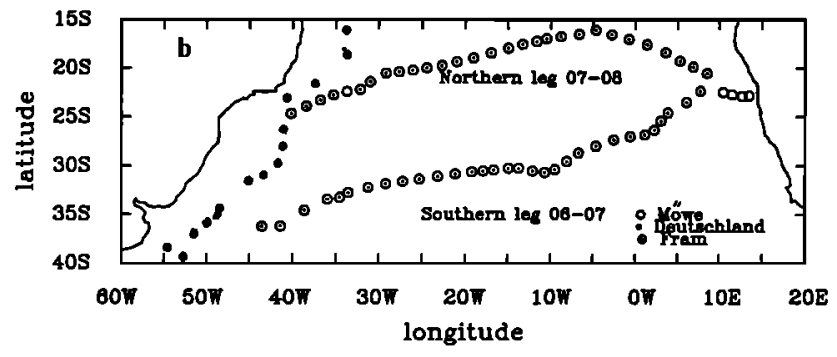

Meteor 1925-26 survey

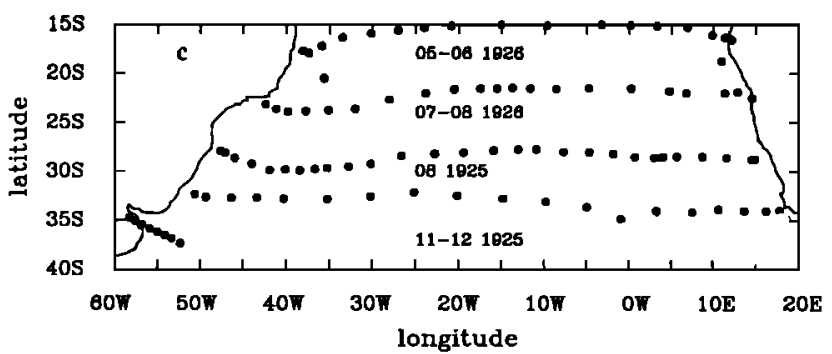

Figure 1. (a) The 1911 hydrographic stations in the equatorial gyre (Deutschland, Möwe, and Stephan). (b) The 1911 hydrographic stations in the South Atlantic subtropical gyre (Deutschland, and Möwe) and the northern and southern legs of the Fram (dates refer to the Fram stations). (c) The 1925-1926 Meteor hydrographic stations in the South Atlantic subtropical gyre. 
season hydrographic structure in the South Atlantic [Levitus, 1982]. North of $10^{\circ} \mathrm{S}$, there are more cruises in all seasons which provide a fairly comprehensive base for estimating the time evolution of thermocline water masses [Merle, 1978], although the first survey after 1911 was conducted in 19261927 (the Meteor expedition), and some of the post-1950 cruises have systematic errors [Mantyla, 1994].

\section{The 1911 Hydrographic Expeditions in the South and Equatorial Atlantic}

The 1911 expeditions of the Deutschland, the Möwe and the Fram (Figure 1b) cover a large part of the South Atlantic subtropical gyre in areas where water masses in the thermocline do not show large spatial variations, except near the continents, so that the stations of the different cruises can be compared. The Deutschland, the Möwe and the Stephan cruises also conducted casts in the equatorial domain. The sampling has particular characteristics for each cruise that we will briefly describe. Details on the sampling techniques and the expected accuracy of the measurements are provided in the appendix.

During the Deutschland expedition, hydrographic casts from surface to bottom were conducted with reversing thermometers and Ekman samplers to collect water for salinity and oxygen measurements. The spatial separation between stations is often larger than $200 \mathrm{~km}$ and extends from $50^{\circ} \mathrm{N}$ to the Weddell Sea. Brennecke [1921] used these data to construct a schematic model of the thermohaline circulation in the Atlantic Ocean, including Antarctic intermediate waters, North Atlantic deep waters, and Antarctic bottom waters. The measurements are well documented, and the samples were analyzed on board with values in the deep waters usually consistent with what one expects. This is also the first significant expedition for which the depth of the collected samples was sometimes measured. Wüst [1935] considered that the material was of a sufficient quality to incorporate it in his atlas of the Atlantic Ocean. In the subtropical South Atlantic these stations in August-September 1911 are from the deep western basins not far from South America, with a vertical resolution coarser or equal to $100 \mathrm{~m}$ in the upper layers.

Approximately at the same time (August to early October 1911), short sections perpendicular to the African coast were undertaken by the Möwe [Schott et al., 1914] during which temperature and salinity were sampled with a vertical resolution of $25 \mathrm{~m}$ in the upper $100 \mathrm{~m}$ and a coarser resolution below. Difficulties in collecting the samples and measuring accurate temperatures were reported, which suggests that the personnel was well trained in hydrographic work, so that most of the temperatures are reliable. The samples were stored for later analysis of chlorinity, and the large scatter for deep water salinity suggests that some of the samples got contaminated before analysis. The sampler used to collect bottom samples probably also leaked during the hauling up. It is not mentioned whether the stations were done while maintaining the wire vertical, though it is likely that this was attempted and only the estimated depth is reported.

A little earlier (mid-June to mid-August 1911), after having landed the Amundsen expedition on Antarctica, the Norwegian vessel Fram undertook a cruise in the South Atlantic between $16^{\circ} \mathrm{S}$ and $34^{\circ} \mathrm{S}$ with a total of 60 stations of the upper $1000 \mathrm{~m}$ of the ocean (Figure 1b). A 22-year-old Russian naval officer,
Alexander Kuchin, who had been briefly trained by Bjørn Helland-Hansen, was in charge of the hydrography [Barr, 1985]. For most stations the 15 levels sampled were at $0 \mathrm{~m}$ (probably from a bucket), 5, 10, 25, 50, 75, 100, 150, 200, $250,300,400,500,750$, and $1000 \mathrm{~m}$, which often provides an adequate resolution in the upper thermocline. Kuchin analyzed the salinity samples in November and December 1911 in Bergen (Norway). A preliminary report of the data is presented by Helland-Hansen and Nansen [1912], who describe the spatial structure of the South Atlantic subtropical gyre. Helland-Hansen and Nansen [1912] commented upon the surface mixed layer in the interior of the gyre with a thickness of the order of $100 \mathrm{~m}$, the density stratification which is highest just below this layer, and the upward slope of upper ocean isopycnals slope toward Africa. However, the report does not provide much information on how the stations were conducted. Unfortunately, some documents were stolen in Buenos Aires, and Kuchin was lost at sea in 1912 before a final report could be presented [Barr, 1985]. The Fram titration book was recently located by Odd Saelen at the Geophysical Institute in Bergen and provides the only information we have on the data.

Finally, in January-February 1911, Merz [1912] on the cable-ship "Stephan" conducted stations whenever possible, as she was laying a cable between Monrovia and Pernambuco. The measurements were done in the upper $800 \mathrm{~m}$, mostly near the surface and within the layer of central water (bottom temperatures were also measured, but those last measurements seem less reliable). The sample salinity was titrated in Kiel and not on board. The depth was estimated and not measured, and in some instances near the equator, the line was certainly not straight, as indicated by a correction done on the depths. The section was presented by Defant [1936], who shows, for the first time, the maximum upper thermocline salinity at the equator and the very large thermocline salinity close to Brazil associated with a thickening of the thermocline in the narrow North Brazil Current. The data lists were kept in the card catalog of the Deutsches Hydrographisches Institut in Hamburg.

In the appendix, we discuss the instrumental errors. A certain number of worrisome deficiencies are noted, in particular for the Fram cruise. For this cruise, temperature is probably not known to better than $0.10^{\circ} \mathrm{C}$ below the mixed layer, and many salinities were rejected because the samples are clearly not from the level indicated or have been contaminated before analysis. We also applied a linear reduction of depth from the reported wire line for eight Fram stations (maximum $18 \%$ for station 55 and larger than $10 \%$ for five stations). The correction results in an average uplift on the two Fram sections of $1.3 \%(13 \mathrm{~m}$ at $1000 \mathrm{~m})$. It is quite possible that the depths reported are still too high, but to an unknown extent. A similar problem might be present for the Möwe and some of the Stephan stations. For the Deutschland stations, on the other hand, when no direct measurement of pressure was made, depth was estimated from the reported wire line using the indicated wire angle, a correction which is not done in the National Oceanographic Data Center (NODC) files. The T-S diagrams of the Möwe and the Stephan stations present a scatter larger than expected, which suggests either a random error of salinity larger than 0.02 or that temperature was not measured at the depth at which water samples were collected. A description of how vertical profiles are constructed from the discrete samples is also provided in the appendix. 


\section{The South Atlantic Subtropical Gyre in 1911}

\section{Sections}

We construct two sections across the South Atlantic, based mainly on the Fram stations, and completed toward Africa by Möwe stations at $22^{\circ} \mathrm{S}-23^{\circ} \mathrm{S}$ and toward South America by some Deutschland stations (Figure 1b). These stations do not resolve the currents along the continental slope, although on the northern leg, Deutschland station 36 in $2275 \mathrm{~m}$ of water should be within the Brazil Current according to Stramma [1989] (in the vicinity of the $40-\mathrm{km}$ ordinate on their Figure 3). The sections are plotted as a function of longitude, both with a depth (Figure 2) and a $\gamma$ coordinate (Figure 3$)\left(\gamma=\rho_{\Theta^{-}}\right.$ $1000 \mathrm{~kg} \mathrm{~m}^{-3}$ is the potential density anomaly, for which we will not further report the unit).

The depth sections (Figures $2 \mathrm{a}$ and $2 \mathrm{~d}$ ) present usually a mixed layer, except close to Namibia, where the thermocline reaches the surface, a consequence of the upwelling near the shelf. The pycnocline is thinner and closer to the sea surface in the eastern Atlantic than near South America and is more spread along the southern leg than along the northern leg. This results in the warmest isotherms on the section for the southern leg being closer to the surface than on the northern leg, but the colder isotherms being deeper for the southern section (Figures $2 b$ and $2 e$ ). Here $\Theta$ and $S$ covary in the thermocline (see the $13.5^{\circ} \mathrm{C}$ isotherm in Figures $2 \mathrm{c}$ and $2 \mathrm{f}$ ), indicating a fairly close $\Theta-S$ relationship, in particular, for the northern leg which is illustrated by nearly horizontal isotherms on the plot with a $\gamma$ coordinate (Figure 3a). Instrumental errors result in some noise on the contours, and we will only comment on the most certain features. The upper thermocline waters above $\gamma=26.7$ have a lower temperature and salinity on isopycnals near Africa. This is probably caused by vertical mixing or heating by penetrating insulation, as these isopycnals are very close to the surface in the Benguela upwelling. The isothermals in the upper thermocline are more saline in the west, in particular, for the southern section (Figures 3a and 3c; also see Figures $2 \mathrm{c}$ and 2f, which indicate that $\mathrm{S}=35.4$ at $13.5^{\circ} \mathrm{C}$ compared to $\mathrm{S}=$ 35.25 farther north). This local maximum found in the density
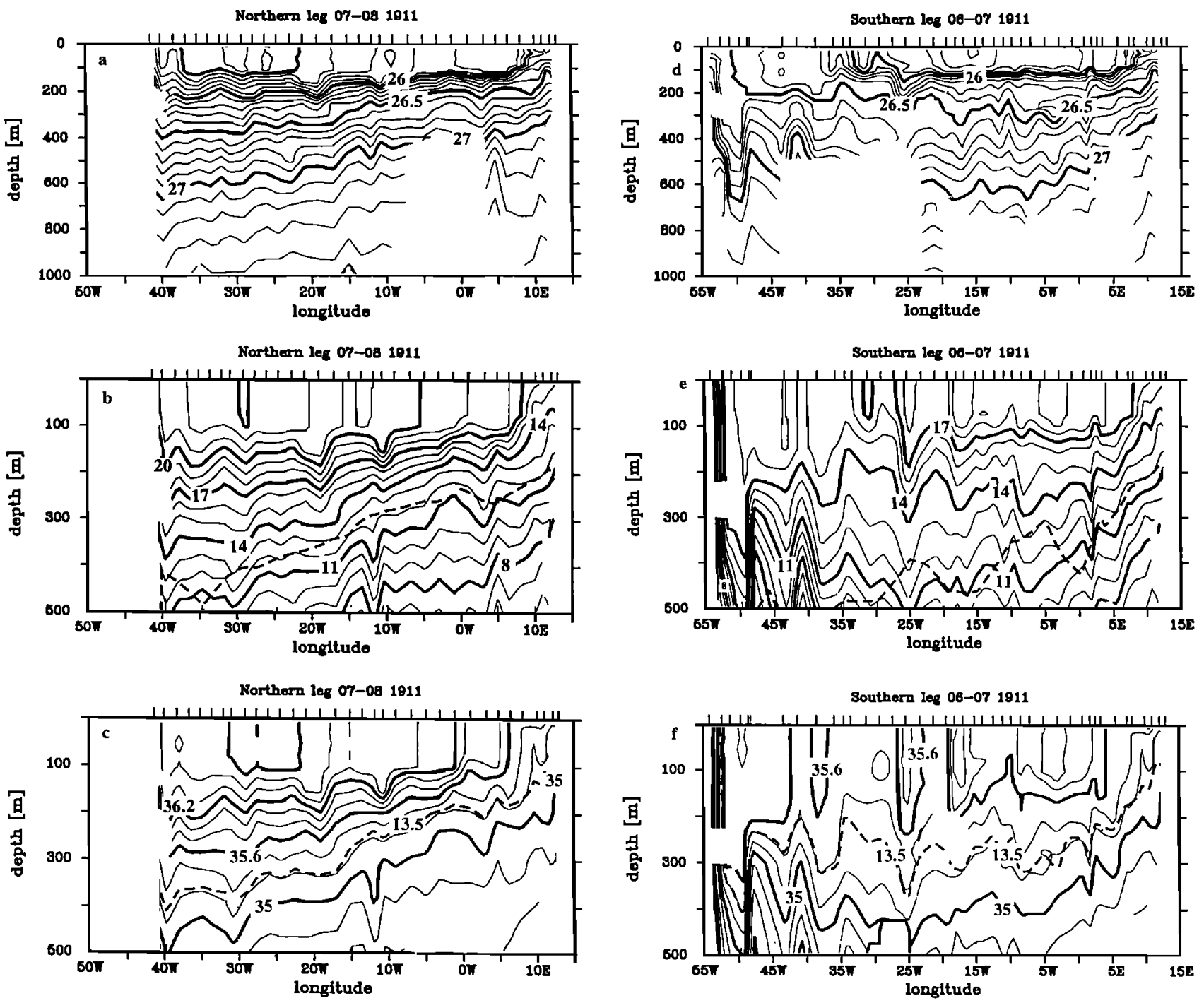

Figure 2. Longitude-depth sections of (a) potential density $(0-1000 \mathrm{~m})$, (b) temperature (0-500 $\mathrm{m})$, and (c) salinity $(0-500 \mathrm{~m}$ ) for the northern leg and the (d) density, (e) temperature, and (f) salinity for the southern leg. For the salinity plots the depths of the $13.5^{\circ} \mathrm{C}$ isotherm is indicated in dashed line. On the temperature plots, the depth of the $11^{\circ} \mathrm{C}$ isotherm from the Meteor $1925-1926$ survey are outlined by dashed lines. 

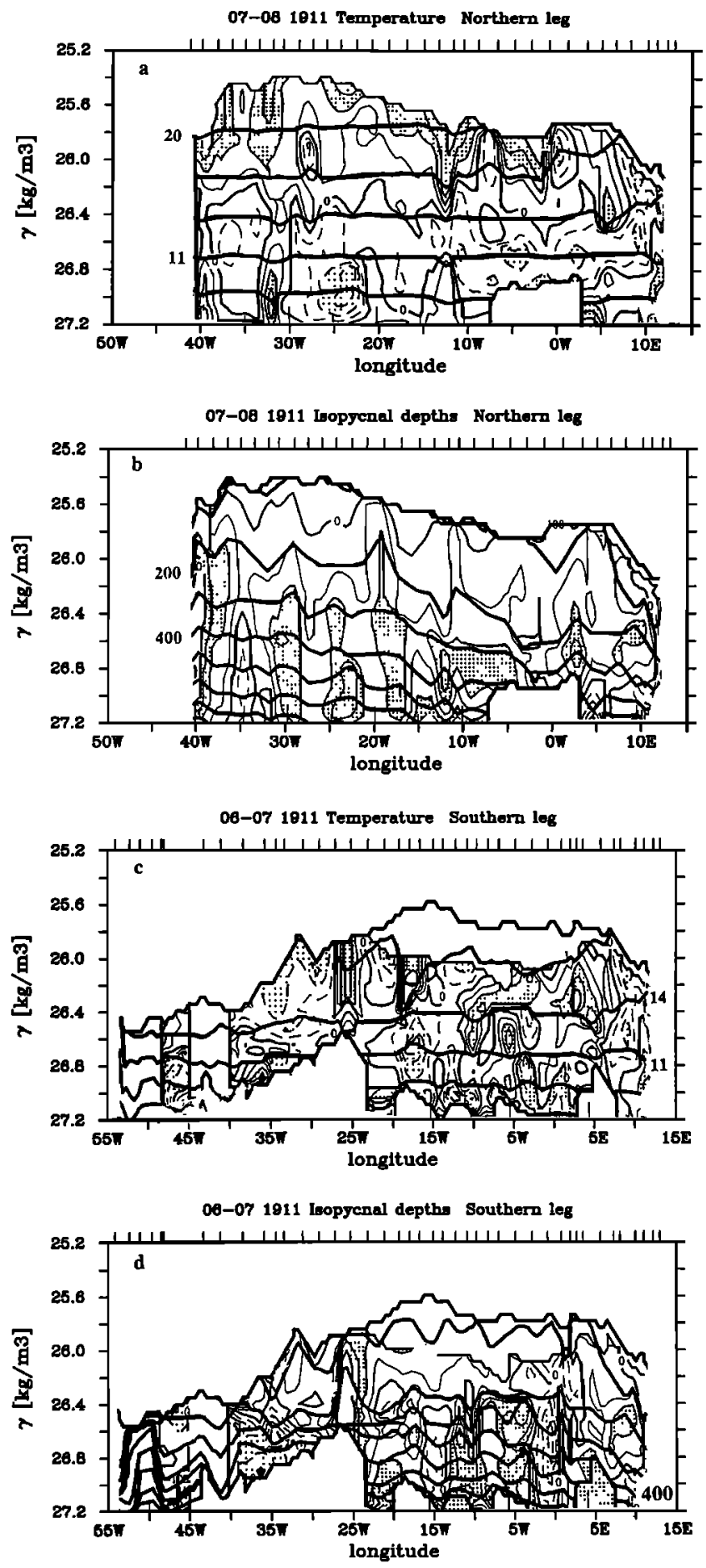

Figure 3. Longitude- $\gamma$ (potential density anomaly) sections of (a) potential temperature and (b) isopycnal depth for the northern leg and the (c) temperature and (d) isopycnal depth for the southern leg of 1911 below the surface mixed layer. The thick solid line in Figures $3 \mathrm{a}$ and $3 \mathrm{c}$ correspond to the isotherms for 1911 stations (every $3{ }^{\circ} \mathrm{C}$ from $5^{\circ} \mathrm{C}$ to $23^{\circ} \mathrm{C}$ ), and on Figures $3 \mathrm{~b}$ and 3d, to the isotherm depths for 1911 (every $100 \mathrm{~m}$ ). The stippled contours (every $0.25^{\circ} \mathrm{C}$ and $25 \mathrm{~m}$ ) correspond to the difference in $\Theta(\gamma)$ or $h(\gamma)$ between 1911 and the 1925-1926 Meteor data interpolated at the same latitude (stipling between $0.5^{\circ} \mathrm{C}$ and $1.0^{\circ} \mathrm{C}$ for the difference in $\mathrm{T}(\gamma)$ and between 50 and $100 \mathrm{~m}$ for the difference in $h(\gamma))$. The ticks over the upper longitude axis indicate the location of the stations. range 26.6-26.8 (T $\left.\sim 11-14^{\circ} \mathrm{C}\right)$ is also a feature noticed on the Meteor sections and on Reid's [1989] maps. It is associated with the Brazil Current and its recirculation and is located below the salty surface water which highest surface density was close to $\gamma=26.56$ in 1911 . This thermocline water slightly undersaturated in oxygen $(\sim 10 \%)$ probably gets its higher salinity from mixing with the salty surface water.

The different isotherms mostly vary together along a section. Notice, however, the isolated bulging between $15^{\circ} \mathrm{C}$ and $16^{\circ} \mathrm{C}$ near $29^{\circ} \mathrm{S} / 7^{\circ} \mathrm{W}$ (Figure 2e). This 100 -m layer of weak vertical gradients is partially resolved by the vertical sampling with its minimum potential vorticity near $200 \mathrm{~m}$ corresponding to a potential density anomaly of $26.30 \mathrm{~kg} \mathrm{~m}^{-3}$ $\left(\mathrm{T}=15.6^{\circ} \mathrm{C}, \mathrm{S}=35.60\right.$ ). This water mass differs from the one at the previous station, which is less salty at that temperature. The deeper isotherms below $15^{\circ} \mathrm{C}$ suggest a fairly large anticyclonic eddy, reminiscent of eddies discussed by Gordon and Haxby [1990] which are shed near the Agulhas retroflection a year earlier. The current salinity and coldest surface water in the retroflection area are 35.60 [Gordon and Haxby, 1990] and $17^{\circ} \mathrm{C}$ [Bottomley et al., 1990]. This temperature is higher than at the 1911 station, a difference which could result from water mass transformation during the hypothetical drift but also from the colder SSTs in the retroflection area in 1911 compared to climatology $\left(-0.5^{\circ} \mathrm{C}\right.$ deviation in July-September 1906-1915 [Bottomley et al., 1990]).

\section{Surface Layer}

Most profiles present a nearly homogeneous layer near the surface. To quantify the mixed layer depth, we adopt the depth where the potential density is higher by $0.05 \mathrm{~kg} \mathrm{~m}^{-3}$ than at the first subsurface level (at $5 \mathrm{~m}$ for the Fram stations). Using a temperature criteria only modifies qualitatively the results and will not be presented (Fram station 3 at $38^{\circ} \mathrm{W}$ on the
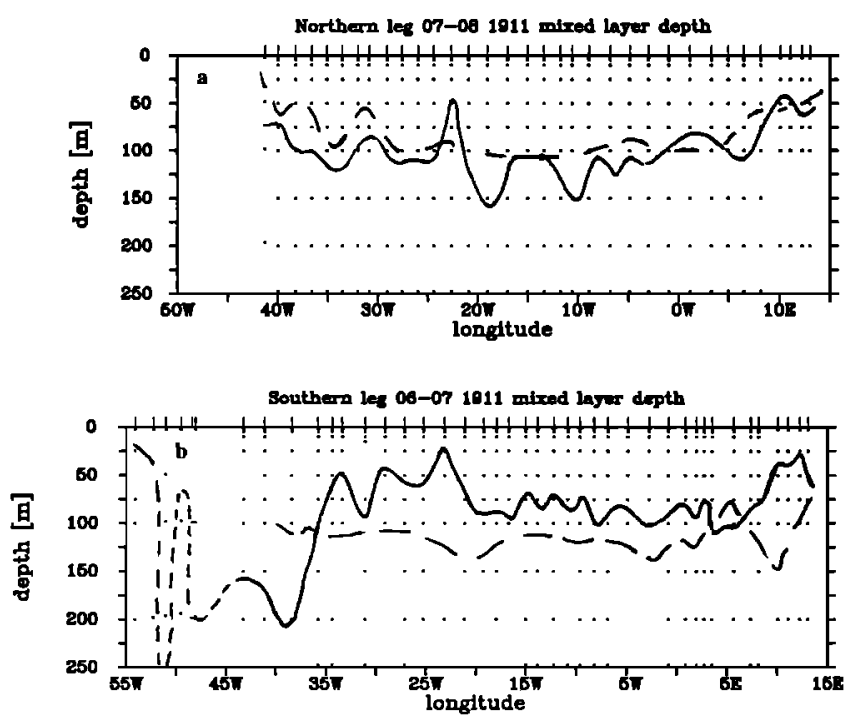

Figure 4. Mixed layer thickness (full line) for the (a) northern and (b) southern sections. The dots indicate where samples were taken. The dashed lines are the mixed layer thickness for the $22-24^{\circ} \mathrm{S} 1926$ Meteor section; (Figure 4a) and the mixed layer thickness for the $28-30^{\circ} \mathrm{S} 1925$ Meteor section (Figure 4b). 
southern leg offers a noticeable exception where salinity increases near $100 \mathrm{~m}$ within a $200-\mathrm{m}$ thick isotherm layer).

The mixed layer thickness is often larger than $100 \mathrm{~m}$ (Figure 4). The isolated shallow mixed layer near $29^{\circ} \mathrm{W}$ on the southern leg is associated with a weak thermal stratification and slightly colder and fresher surface water. The shallower mixed layer near Africa is related to the uplift of the thermocline (Figure 2). The mixed layer is usually a little thicker along the northern section than along the southern section. Part of the difference results from the northern section being later in the winter than the southern one. Along the southern section, thick surface mixed layers $(200 \mathrm{~m}$ or more) are found west of $38^{\circ} \mathrm{W}\left(33^{\circ} \mathrm{S}\right.$ to $37^{\circ} \mathrm{S}$ ) (Figure 4b). Deep mixed layers are also observed at Deutschland stations in the Brazil Current between $34^{\circ} 23^{\prime} \mathrm{S} / 48^{\circ} 10^{\prime} \mathrm{W}$ and $39^{\circ} 21^{\prime} \mathrm{S} / 52^{\circ} 17^{\prime} \mathrm{W}$, with surface temperatures between $14.80^{\circ} \mathrm{C}$ and $15^{\circ} \mathrm{C}$ and salinity within 0.02 of 35.70 (maximum density anomaly 26.56). These stations collected between August 28 and October 9 are close to the coldest time of the year. Fram station 3 in late June at $34^{\circ} 34^{\prime} \mathrm{S} / 38^{\circ} 24^{\prime} \mathrm{W}$ has a comparable salinity and a warmer $\left(15.6^{\circ} \mathrm{C}\right)$ temperature which could be the same water mass earlier in the seasonal cycle. The other Fram deep mixed layers contain another water mass.

The synoptic scale surface variability of $\mathbf{T}$ and $\mathbf{S}$ is large along the southern leg, with a peak-to-peak amplitude of 1 to $2{ }^{\circ} \mathrm{C}$ and up to 0.5 in salinity (Figure 5). The apparent wavelength of these fluctuations is of the order of 650 to 750 $\mathrm{km}$, a very uncertain estimate because of the insufficient sampling. Temperature and salinity are correlated on this scale, but the density is not, suggesting the vicinity of the subtropical front. The surface fluctuations are also experienced in the subsurface upper thermocline water mass with high surface salinity corresponding to high salinity on subsurface isotherms. The lower thermocline water mass does not present
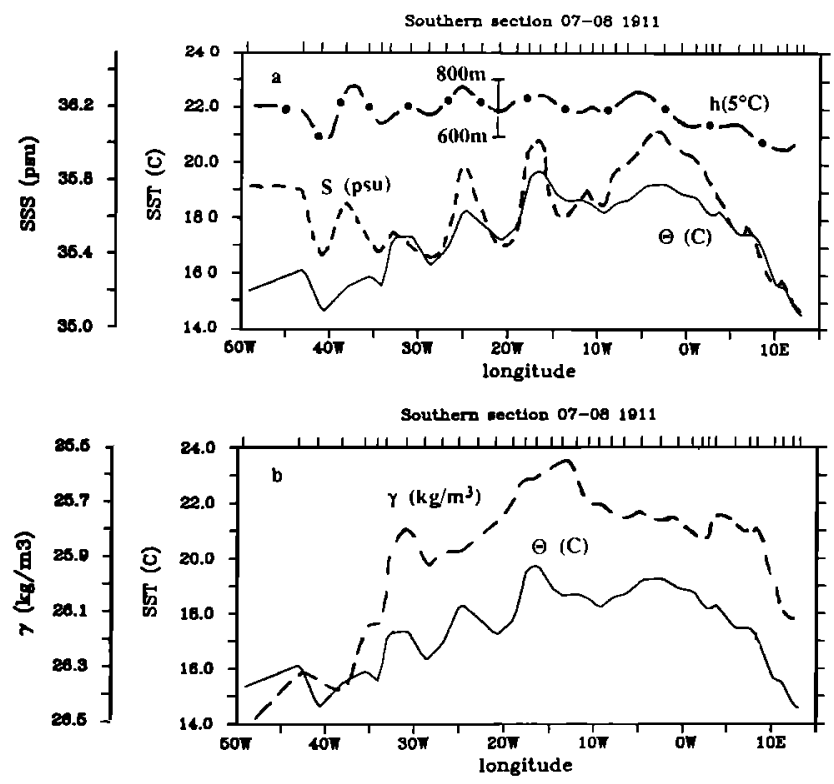

Figure 5. (a) Surface properties and (b) isotherm depths along the southern section in 1911. In Figure 5a, the solid line is for sea surface temperature (SST), the dashed line is for salinity, and the dashed-dotted line is for the depth of the $5^{\circ} \mathrm{C}$ isotherm (reversed scale). In Figure $5 \mathrm{~b}$, the solid line is for SST and the dashed line is for surface density anomaly (reversed scale). similar variability (Figure 3c), so that the leg is to the north of the South Atlantic current, in agreement with the expectation that the core of eastward velocity is expected farther south [Peterson and Stramma, 1991]. West of $10^{\circ} \mathrm{W}$ (between $35^{\circ} \mathrm{S}$ and $31^{\circ} \mathrm{S}$ ), the $5^{\circ} \mathrm{C}$ isotherm depth also fluctuates with shallow isotherms (or isopycnals) corresponding to a cold and fresh surface water (Figure 5a). The 1911 along-section variability probably results from meanders of the eastward current, where the uplift of the thermocline in the middle of an anticyclonic meander is associated with colder and fresher surface water originating farther south. This could, for example, correspond to synoptic scale rings and meanders, which have being observed on satellite imagery far to the east of the Brazil-Malvinas convergence [Olson et al., 1988].

We will also briefly mention that in addition to the surface mixed layer, the southern section presents a subsurface layer of reduced gradients in the thermocline centered at $13-14^{\circ} \mathrm{C}$ or $\gamma=26.5-26.7$ between $35^{\circ} \mathrm{W}$ and $17^{\circ} \mathrm{W}$ (Figures $2 \mathrm{e}$ and 6). $\mathrm{A}$ weaker bulging of the thermocline is also observed along the $28^{\circ}-30^{\circ} \mathrm{S} 1925$ Meteor section west of $25^{\circ} \mathrm{W}$. Along the $34^{\circ} \mathrm{S}$ 1925 Meteor section it is present west of $15^{\circ} \mathrm{W}$ with a more intense weakening of the stratification (lower potential vorticity). This mode water along $34^{\circ} \mathrm{S}$ in 1925 is also slightly lighter than $26.60 \mathrm{~kg} \mathrm{~m}^{-3}$. At the $28^{\circ} \mathrm{S}$ Meteor section, what remains of it is denser and around $26.60 \mathrm{~kg} \mathrm{~m}^{-3}$. McCartney [1977, 1982] describes a mode water in 1959 along a $32^{\circ} \mathrm{S}$ International Geophysical Year (IGY) section in the 26.53-26.62 range, therefore a little lighter than in 1925 . The density range in 1911 roughly corresponds to the subtropical mode water (STMW) described from recent surveys by Tsuchiya [1986], although both Roden [1989] and Gordon [1981] present sections with a slightly lighter modem water. Both in 1911 and in more recent surveys, the mode water differs from the winter surface water characteristics of the deep mixed layers of the Brazil Current, with which it shares a similar density but is significantly colder (at least $1^{\circ} \mathrm{C}$ ) and fresher (at least 0.3 ) in 1911. Interestingly, Fram station 2 by $41^{\circ} 7^{\prime} \mathrm{W} / 36^{\circ} 12$ 'S which has a slightly shallower mixed layer $(150 \mathrm{~m})$ than the Deutschland stations in the recirculation of the Brazil Current, a surface water temperature of $14.7^{\circ} \mathrm{C}$ but a fresher salinity of 35.40 is a much more likely candidate for producing the subsurface water by winter cooling. This water mass is likely to result from transformation of the subtropical water of the Brazil current with a salinity of 35.70 by mixing

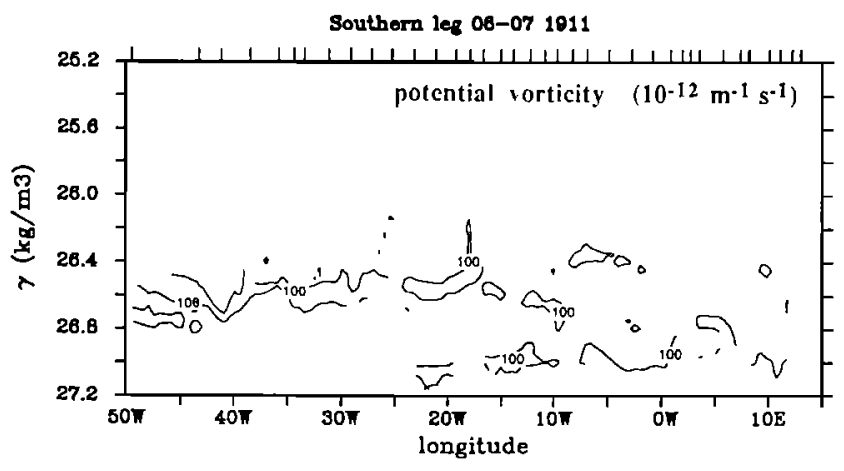

Figure 6. Southern leg. longitude- $\gamma$ section of potential vorticity $f / \rho(\partial \rho / \partial z)$, where $\partial \rho / \partial z$ is the potential density gradient at the depth considered (as in the work of McCartney [1977]) (only the $100 \times 10^{-12} \mathrm{~m}^{-1} \mathrm{~s}^{-1}$ contour is plotted). 
with the fresher Malvinas Current waters, as suggested by the water mass analysis of Maamaatuaiahutapu et al. [1992].

Along the northern section, surface variables vary more smoothly, with a salinity increase from east (Namibia) to $25^{\circ} \mathrm{W}$, where it nearly reaches 37.00 . The largest salinity increase $\left(0.35\right.$ within $2^{\circ}$ longitude) is observed near $0^{\circ} \mathrm{W}$, which could correspond to a front between different water masses: station 36 at $17^{\circ} 32^{\prime} \mathrm{S} / 1^{\circ} 06^{\prime} \mathrm{E}$ to the east of this transition has surface $T$ and $S$ close to those found near $27^{\circ} \mathrm{S} / 0^{\circ} \mathrm{W}$, whereas stations to the west of station 37 have slightly warmer and more salty surface waters with a comparable density.

\section{Equatorial Section}

The Stephan section is drawn by Defant [1936], and we will only briefly present this interesting section between Sierra Leone and Brazil (Figures 1a and 7). The temperature section (density section) presents a thinner and steeper upper thermocline north of the equator than south of it where it is deeper (Figures 7a and 7c). The thermocline slope near $5^{\circ} \mathrm{N}$ is indicative of the eastward flowing Guinea current. There is a broadening of the upper thermocline near the equator which suggests that the core of the Equatorial Undercurrent was located near $50 \mathrm{~m}$, slightly above the high-salinity core originating from the North Brazil Current. Surface temperature presents a minimum near the equator indicative of the equatorial upwelling, and there is a strong salinity front just north of the equator, so that surface water is much lighter north of the equator than south of it. South of the equator, the geostrophic current in the upper thermocline is almost everywhere westward. This is probably the earliest section to illustrate the increased slope of the pycnocline south of $6^{\circ} \mathrm{S}$ associated with the North Brazil Current, whose geostrophic core is located near $150 \mathrm{~m}$ below the salinity core. Recent sections typically show similar features (for instance, the 1982-1984 Programme Français Océan-Climat en Atlantique Equatorial (FOCAL) surveys by Hisard and Hénin [1987] or sections close to Brazil by Stramma et al. [1995]).

A section of temperature with $\gamma$ as a vertical coordinate is also presented (Figure 7d), which shows little spatial gradient of the water mass for $\gamma$ between 26.5 and 27.0, except in the vicinity of South America where the water masses have characteristics close to the ones in the South Atlantic subtropical gyre (Figure 3a). The density corresponding to the upper thermocline isotherms (for example $20^{\circ} \mathrm{C}$ in Figure 7d) decreases usually from south to north, with a relative maximum in the vicinity of the equator, corresponding to the water of recent South Atlantic origin flowing in the Equatorial Undercurrent.

\section{Deviation From Climatology and More Recent Surveys}

\section{Water Masses}

We compared the $\Theta(S)$ curves of different cruises, which suggest an evolution of the water masses, both in the subtropics and equatorial domain. To illustrate these changes in the subtropics, we will compare sections of temperature on isopycnal surfaces $(\Theta(\gamma))$. When two sections bracket in latitude the 1911 stations (as in 1925-1927 or in 1957-1959), $\Theta(\gamma)$ is first linearly interpolated between the two sections to the latitude of the 1911 stations. The linear interpolation in the subtropical gyre provides a reasonable approximation, with resulting errors in $\Theta(\gamma)$ probably less than $0.10^{\circ} \mathrm{C}$ in the thermocline. The zonal section of the $\Theta(\gamma)$ difference between
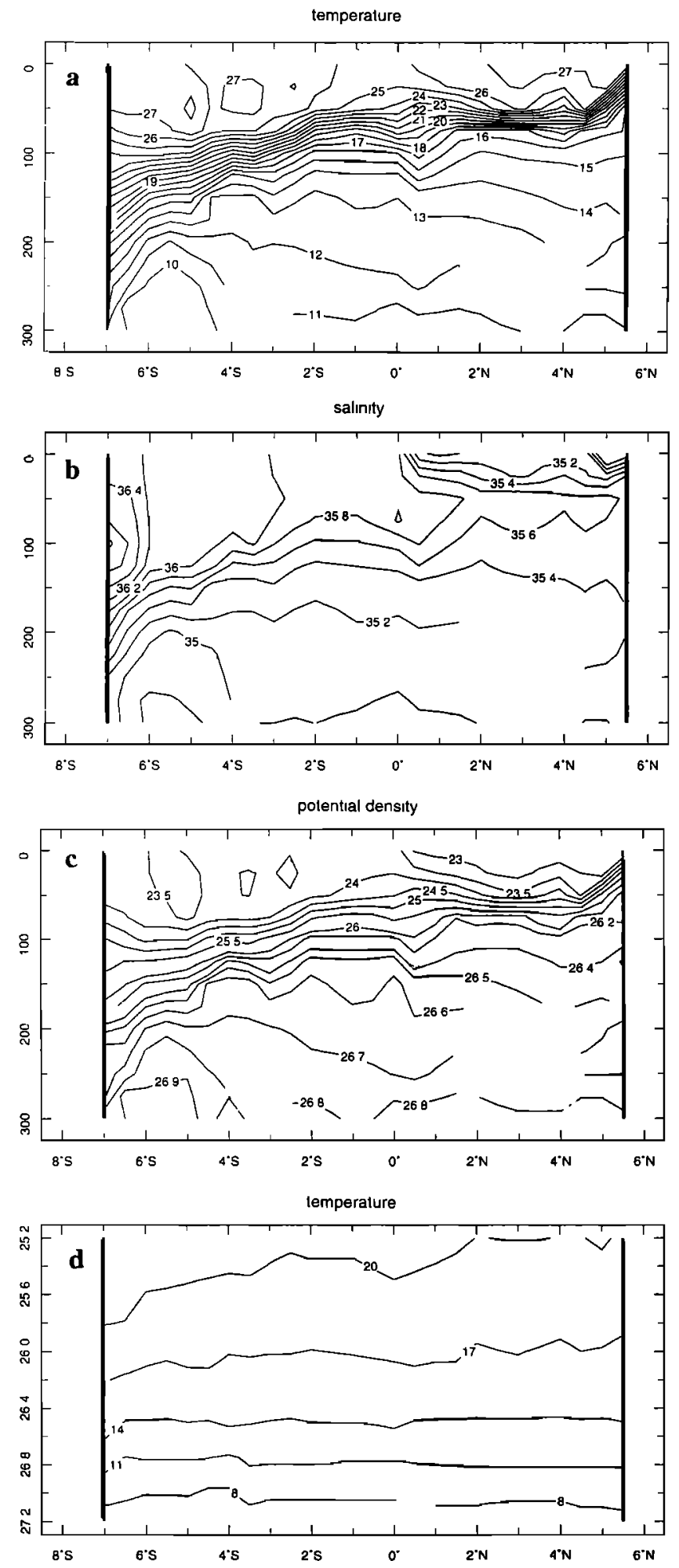

Figure 7. Latitude-depth $(0-300 \mathrm{~m})$ sections of (a) potential temperature, (b) salinity $(0-500 \mathrm{~m})$, and (c) potential density for the Stephan cruise in January-February 1911 (compare with Figure 1a). (d) Latitude-potential density Stephan section of temperature. 
the 1911 northern leg and the Meteor survey in 1925-1926 indicates (Figures 3a and 3c) generally higher $\Theta(\gamma)$ in 1911 than in 1925-1926 in the upper water column (roughly, a 200$\mathrm{m}$ thick layer down to $\gamma=26.4$ ) and lower $\Theta(\gamma)$ below down to the Antarctic intermediate water. This corresponds to a steeper slope of the $\Theta(S)$ curve in 1911 than in 1925 (Figure A1). The maximum zonally averaged differences are of the order of $0.40^{\circ} \mathrm{C}$ at $\gamma=25.9(\approx 150 \mathrm{~m})$ and of -0.23 at $\gamma=26.7(\approx 350 \mathrm{~m})$. The southern leg $\Theta(\gamma)$ differences between 1911 and the Meteor survey in 1925-1926 are more noisy, and zonally averaged differences east of $35^{\circ} \mathrm{W}$, which are slightly negative between $26.5(\approx 200 \mathrm{~m}$ depth) and 26.90 , i.e., colder and fresher, are not significant.

Interestingly, the differences are even larger when comparing to IGY (1957-1959), and are negative throughout the density range (Table 1a). Mantyla [1994] comments that IGY salinities are too high, which could correspond to a $0.10^{\circ} \mathrm{C}$ overestimate of $\Theta(\gamma)$ for $\lambda<26.8$, less than these differences. Compared with IGY, waters in 1925-1926 are colder and fresher on isopycnal surfaces above 27.0 , which is found for the three Meteor sections of $16^{\circ} \mathrm{S}, 21-24^{\circ} \mathrm{S}$ (Figure $8 \mathrm{a}$, and $28-30^{\circ} \mathrm{S}$. This indicates a shift of the $\Theta-S$ relationship between the two surveys (and a lesser slope in 1957-1959 than in 1925-1926). IGY waters at $24^{\circ} \mathrm{S}$ are warmer (saltier) than in 1983 (Oceanus cruise) above 26.6 and are warmer (saltier) than in 1988-1989 (South Atlantic Ventilation Experiment (SAVE) survey at $24-31^{\circ} \mathrm{S}$ ) above 26.8-27.0 (Figure $8 \mathrm{~b}$ and $8 \mathrm{c}$ ). These two recent surveys have thermocline water mass characteristics fairly similar to those in 1925-1926 (Table 1a).

The situation near the equator is less clear but deserves some comments. There, it is more difficult to compare different sections of $\Theta(\gamma)$ because of larger spatial or seasonal variability, in particular above $\gamma=26.4$ and below $\gamma=27.0$. Also, the Stephan data present a $S(\Theta)$ scatter of at least 0.02 , larger than for recent cruises, and a slight tendency for its $S(\Theta)$ to be located at a higher salinity than nearby 1911 Deutschland stations. The difference between the $1911 \Theta(\gamma)$ section with nearby Meteor cruises in 1926 presents a difference averaged along the section between $-0.09^{\circ} \mathrm{C}$ and $0.12^{\circ} \mathrm{C}$ below $\gamma=26.4$. This is barely significant, considering the variability of the differences along the section ( $\mathrm{rms}$ of the order of $0.15^{\circ} \mathrm{C}$ between 26.4 and 26.7 and larger outside of that range), as well as the possibility of systematic errors of a comparable magnitude. We also grouped the stations by latitude range and constructed an average $S(\Theta)$ curve for different surveys (Figure 9). The 1911 and 1926 data for densities lighter than 26.7 indicate colder $\Theta(\gamma)$ by $0.2^{\circ} \mathrm{C}$ compared with the numerous surveys in the 1980 s which consistently have a high accuracy. For this density range one has therefore the impression that the evolution found farther south between 1911,1926 and 1957 is also found at the equator but later on. This is compatible with the equatorial water originating mainly from the southern hemisphere and its larger ventilation age. At 26.8 and deeper the evolution is not so coherent between different latitudes, although Figure $7 \mathrm{~d}$ also suggests an increase.

\section{Surface Water}

It is reasonable to expect that the changes in the thermocline water masses would originate at the surface, in particular, in late winter. The changes in the surface water are more difficult to ascertain from hydrography, because the different sections correspond to different times of the seasonal cycle, which, in particular for salinity, is poorly resolved in the South Atlantic [Krauss, 1962]. Zonally averaged deviations from the SST climatology based on Comprehensive Ocean-Atmosphere Data Set (COADS) 19501979 monthly statistics on a $2^{\circ} \times 2^{\circ}$ grid [Wright, 1988] are presented in Table $1 \mathrm{~b}$ for the few cold season surveys (JulyOctober). These averages suggest strong negative anomalies in 1911 in the South Atlantic subtropical gyre. The 1911 equatorial Stephan data (not presented) are also much colder than normal, although this could also be related to the year-toyear variability taking place near the equator. Anomalies for the $22-24^{\circ} \mathrm{S}$ and $28-30^{\circ} \mathrm{S}$ sections in $1925-1926$ are less negative than in 1911 . The deviation in October $1958\left(24^{\circ} \mathrm{S}\right)$ is positive, but it is less representative of the coldest season, because the upper layer was already stratified at the time of the survey.

The Levitus [1982] climatology of near surface salinity is based on few stations away from the continental shelves for this season and is strongly influenced by the few sections in 1925-1926 and 1958, so the zonally averaged deviation of sea surface salinity (SSS) from climatology for these cruises does not exceed 0.01 (first subsurface level compared in order to avoid bucket errors). The 1911 Fram data were not included in the Levitus [1982] climatology, and the zonally averaged deviations from climatology indicate fresher waters in 1911 , -0.066 and -0.020 for the northern and southern legs, respectively. The result for the southern leg is not significatively nonzero, because of the high spatial

Table 1a. Deviations of Zonally Averaged $\Theta(\gamma)$ for Various Cruises With Respect to the Meteor 1925-1926 Survey

\begin{tabular}{llllll}
\hline & \multicolumn{5}{c}{ Potential Density Anomaly $\gamma$} \\
\cline { 2 - 5 } & 26.4 & 26.6 & 26.8 & 27.0 & 27.1 \\
\hline Northern leg, 1911 & -0.03 & -0.20 & -0.19 & -0.02 & 0.04 \\
$24^{\circ}$ S, October 1958 & 0.30 & 0.22 & 0.18 & 0.05 & -0.01 \\
$24^{\circ}$ S, 1983 & 0.03 & 0.09 & 0.13 & 0.04 & -0.03 \\
Southern leg, 1911 & 0.01 & 0.00 & -0.06 & 0.02 & -0.05 \\
$28^{\circ}$ S, 1959 & 0.16 & 0.15 & 0.10 & 0.01 & -0.01 \\
Southern SAVE,1987-1989 & -0.12 & -0.10 & -0.02 & 0.01 & \\
\hline
\end{tabular}

All values are in degrees Celsius. The two legs of 1911 are presented, as well as other sections for the same season (salinity error in 1957-1959 and 1983 [Mantyla, 1994] could induce a positive bias in $T$ of up to $0.10^{\circ} \mathrm{C}$ at $\gamma=26.4-26.8$ ). 
Table 1b. Zonally Averaged Deviations of Surface Properties From Climatology for Various Sections

\begin{tabular}{lrcl}
\hline & SST-SSTA & SST-SSTB & SSS-SSSB \\
\hline Northern leg, 1911 & -0.77 & -0.39 & -0.066 \\
Southern leg, 1911 & -0.87 & -0.10 & -0.020 \\
$22-24^{\circ}$ S, July-August 1926 & -0.26 & 0.37 & -0.023 \\
$28-30^{\circ}$ S, August 1925 & -0.73 & -0.39 & -0.019 \\
$24^{\circ}$ S, October 1958 & 0.28 & $0.16^{*}$ & $0.010^{*}$ \\
\hline
\end{tabular}

SST is sea surface temperature (degrees Celsius), SSS is sea surface salinity. A refers to the Wright [1988] climatology based on the Comprehensive Ocean-Atmosphere Data Set 1950-1979; B refers to the seasonal Levitus [1982] climatology based on hydrographic data and taken at the first subsurface level.

* The climatology for August-October in the central Atlantic is probably strongly influenced by that section.

variability (rms difference of 0.15 , corresponding to an $\mathrm{rms}$ error on the zonal average of 0.03 ), and even for the northern leg, the results are not very certain. For example, eliminating for the northern leg stations east of $0^{\circ} \mathrm{W}$ results in a larger -0.112 averaged SSS anomaly. The occurrence of fresher 1911 surface water is also supported by the comparison with other sections interpolated at the position of the 1911 stations: the averaged deviations with the 1925-1926 survey are (-0.05, -0.05 ) for the northern and southern legs (similar even after removing stations east of $0^{\circ} \mathrm{W}$ ). For the northern leg we should, however, comment that the 1925-1926 sections in late May-July are at an earlier time of the seasonal cycle than the Fram stations. The average seasonal cooling between the two surveys is $-0.85^{\circ} \mathrm{C}$, so that seasonally corrected temperature differences between the two surveys are $-0.75^{\circ} \mathrm{C}$. The seasonal cooling is associated with a mixed layer deepening (coherent with the comparison in Figure 4) and therefore with an entrainment of deeper, fresher water. On the basis of the observed $\Theta-S$ relationship, this could result in a 0.012 surface freshening. High loss of water at the air-sea interface in that season would probably correspond to an increase. It is therefore unlikely that the seasonally corrected deviation of 1911 with respect to 1925-1926 is less than -0.035 for the northern leg. The comparison of the $24^{\circ} \mathrm{S}$ October 1958 section with the interpolation between the 22$24^{\circ} \mathrm{S}$ July 1926 section and the $28-30^{\circ} \mathrm{S}$ August 1925 section suggests that surface salinity was 0.04 higher in 1925-1926 than in 1958 (0.03 after including poorly known seasonal variations). In 1958 the surface layer was quite stratified, so that the SST difference after the 1925-1926 survey is not representative of the cold season.

The subsurface waters of the subtropical gyre are formed in late winter, so that winter surface $T$ and $S$ differences should be related to differences in the subsurface $S(\Theta)$. We find that the $\mathrm{S}(\Theta)$ relation which has a slope of at least 0.10 for $0.6^{\circ} \mathrm{C}$ is more influenced by the observed surface temperature changes than by the salinity changes. A cooling at the surface with no freshening induces positive deviations of temperature and salinity on isopycnal surfaces because of the slope of the $S(\theta)$ relationship. From the average $S(\Theta)$ and the surface anomalies one predicts that $\Theta(\gamma)$ will be larger by $0.45^{\circ} \mathrm{C}$ in 1911 than in 1925-1926. This is fairly close to what is observed for these density levels, which are mostly ventilated within the Atlantic subtropical gyre. On the other hand, to explain the

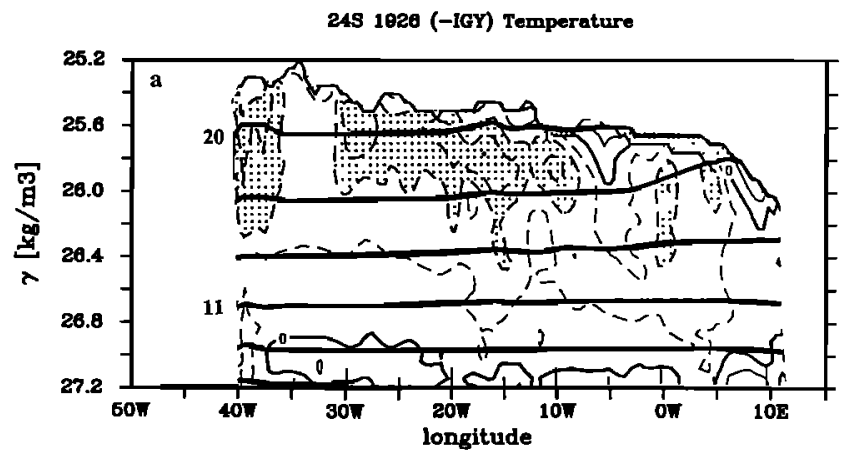

$24 S 1983$ (-IGY) Temperature

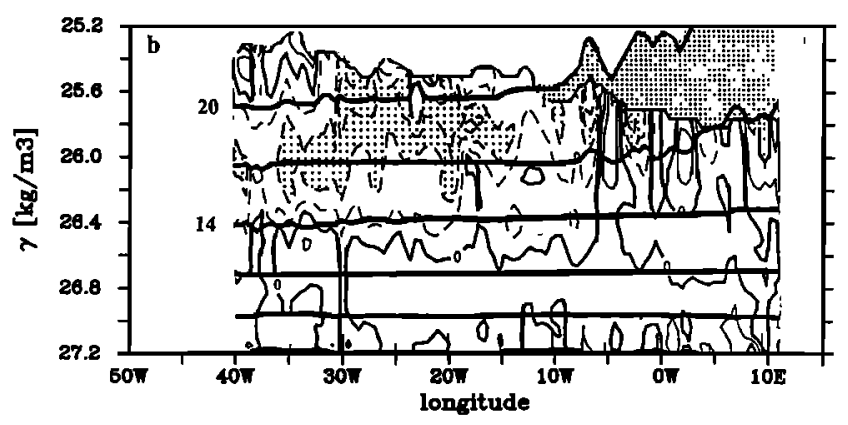

24S-31S 1988-1989 (-IGY) Temperature

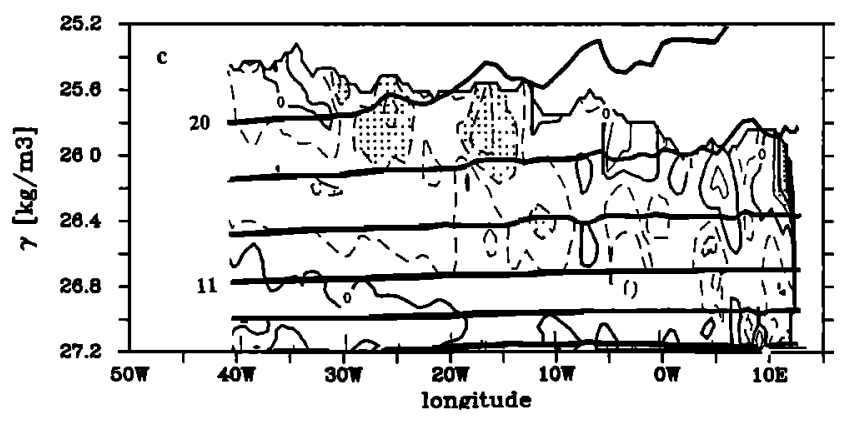

Figure 8. Same as temperature in Figure $3 a$, but for more recent sections (stippled areas between $0.5^{\circ} \mathrm{C}$ and $1.0^{\circ} \mathrm{C}$ for the difference in $\mathrm{T}(\gamma)$ ), (a) $22-24^{\circ} \mathrm{S}$ July 1926 Meteor section compared with International Geophysical Year (IGY) $24^{\circ} \mathrm{S}$ section, (b) Crawford $24^{\circ} \mathrm{S}$ compared with 1983 Oceanus 1983 section, and (c) $23^{\circ} \mathrm{S}-31^{\circ} \mathrm{S} 1988-1989$ section compared with IGY 1958-1959 sections.

change in the $S(\Theta)$ relationship between 1925-1926 and 1958 at $24^{\circ} \mathrm{S}$ would require that 1958 was colder than $1925-1926$, of which we have found no evidence. We should not apply this simple reasoning farther down in the water column, where water originates from the Indian Ocean and the sub-Antarctic according to Gordon et al. [1992] and for which we donot have past records of surface conditions. These are also less recently ventilated waters, so that high-frequency interannual fluctuations should be damped considerably. The ventilation age increases from a few years for $\gamma \sim 26.4$ to up to 30 years at the highest densities of the subtropical waters [Warner and Weiss, 1992].

\section{Mixed Layer and Isotherm Depths}

The differences between the 1911 and 1925-1926 mixed layers have a different sign for the northern and the southern 

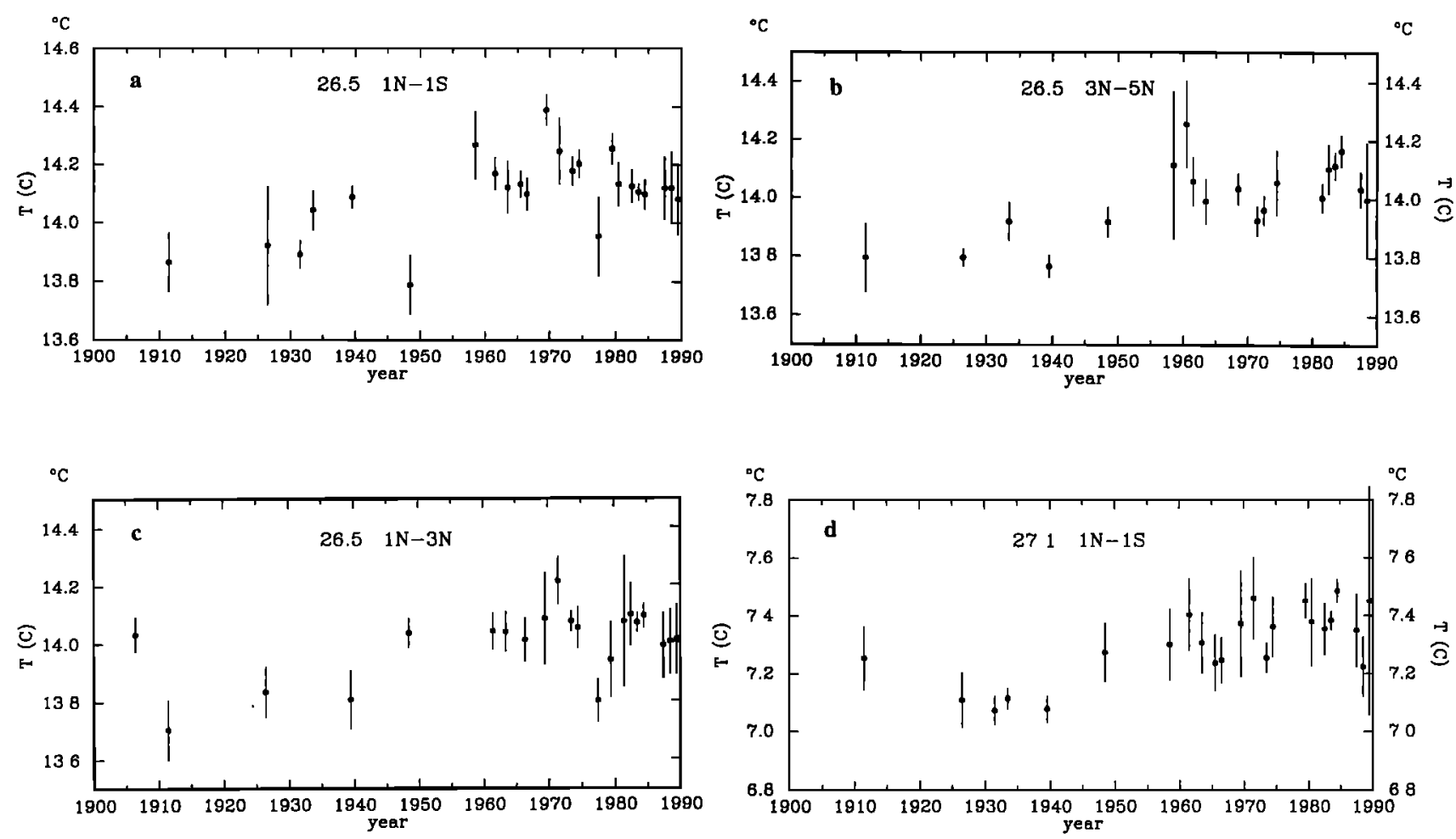

Figure 9. Time evolution of $\Theta(\gamma)$ in the central equatorial Atlantic for (a) $1^{\circ} \mathrm{N}-1^{\circ} \mathrm{S}$, (b) $3^{\circ} \mathrm{N}-5^{\circ} \mathrm{N}$, (c) $1^{\circ} \mathrm{N}-3^{\circ} \mathrm{N}$, and (d) $1^{\circ} \mathrm{N}-1^{\circ} \mathrm{S}$ (most data are bottle data from Nansen casts, either from National Oceanographic Data Center archives or from the South Atlantic Ventilation Experiment, French and German cruises). Data are grouped by year whose averages $\Theta(\gamma)$ are plotted, as well as the \pm 1 standard deviation of the estimated error on the mean (vertical bars).

legs (Figures 4a and 4b). On the other hand, the mixed layer depth for the same month, albeit not in the same part of the gyre, are comparable (July 1926 along $22^{\circ} \mathrm{S}$ with the 1911 southern leg or July-August 1925 along $28^{\circ} \mathrm{S}$ with the northern leg). This suggests that the main signal results from the seasonal deepening of the mixed layer from July through September, which occurs throughout the subtropical gyre, and that the range of mixed layer depths is comparable in 19251926 and in 1911. There are also differences between the 1911 mixed layers and the mixed layer depth climatology of Lamb [1984] that could originate from the small number of profiles included in this climatology; for example, the shallow mixed layer depth of Lamb [1984] near $20^{\circ} \mathrm{W}$ in July-August is a doubtful feature. The 1911 deep mixed layers south of $34^{\circ} \mathrm{S}$ offshore of the Brazil Current are also found in other surveys in that season but often with a warmer temperature. For example, in September 1989 the mixed layer whose thickness also exceeded $200 \mathrm{~m}$ had a warmer and saltier water [Maamaatuaiahutapu et al., 1992]. The surface warming between 1911 and 1989 probably also explains why the subtropical mode water is denser in recent surveys compared with 1911.

The isotherms in the subtropical thermocline in 1911 are often deeper than those linearly interpolated to the same positions from the Meteor 1925-1926 sections (Figures 2b and $2 \mathrm{~d}$ ). This happens everywhere along the northern leg, except in the immediate vicinity of Africa, and whether it is from stations of the Möwe, the Deutschland, or the northern Fram section is unknown. This also happens along the southern leg east of $30^{\circ} \mathrm{W}$. The maximum change in isotherm depth of the order of $45 \mathrm{~m}$ occurs near $300 \mathrm{~m}(\gamma=26.8)$ (Figure $3 \mathrm{~b}$ and 3d). The comparison with the Levitus [1982] climatology produces anomalies of the same sign, albeit a little smaller (same results for the depth of isopycnals and isohalines). Although this is likely to be real, it is also possible that the estimated depth was overestimated for the Fram and the Möwe stations. Near the equator, the upper thermocline isotherm depths of the Stephan section are found to be $20 \mathrm{~m}$ shallower than in recent surveys for that season. This seems too large to result from high-frequency variability and could be a manifestation of interannual variability of a magnitude comparable to the one found in recent years.

\section{Conclusion}

The cruise of the Fram in the South Atlantic subtropical gyre during June-September 1911 and of the Stephan in the equatorial Atlantic in January-February 1911 complement the better known Deutschland and Möwe expeditions in the same year. Together, they provide a hydrographic survey of the South Atlantic subtropical gyre, except for the western boundary currents, and of the equatorial Atlantic, which, at the least, is of historical value. The data of temperature and salinity were more accurate than during earlier surveys (for instance, the Challenger and Gazelle cruises in 1873-1876) but still present larger uncertainties than during later expeditions. Except for a few Deutschland stations, depth was not measured but estimated from the wire out, and we are not 
certain that the wire was always hanging vertically. The vertical and horizontal resolution achieved in the upper thermocline during the Fram cruise was not exceeded in the South Atlantic until the last decades, so that these data are still valuable, in particular, to provide an account of the hydrographic conditions during the cold season.

The main hydrographic features of the subtropical South Atlantic in 1911 are as follows: a surface mixed layer of thickness exceeding $100 \mathrm{~m}$ found at most stations, except close to Africa; a thermocline stratification highest in the eastern Atlantic and weakest in the southwest portion of the survey; a thermocline tilted upward toward the east at these longitudes; and a variability of surface water along the southern leg correlated with vertical displacements of the thermocline. Stations of the Deutschland between $34^{\circ} 23^{\prime} S$ and $39^{\circ} 21^{\prime} \mathrm{S}$ offshore from the Brazil current present very deep mixed layers, with water of subtropical origin at a temperature between $14.80^{\circ} \mathrm{C}$ and $15^{\circ} \mathrm{C}$ and a salinity within 0.02 of 35.70. A layer of reduced density gradient is embedded in the thermocline west of $20^{\circ} \mathrm{W}$ at the same density. However, this water has a lower $\mathbf{T}$ and $\mathrm{S}$ than the deep mixed layers in the west, and therefore does not result directly from their subduction. The $\Theta(S)$ properties in 1911 show relatively uniform subsurface water masses across a large stretch of the subtropical gyre (Figures 3a, 3c, and A1). In the east, shallow isopycnals are a little colder and fresher, while in the west the upper thermocline isopycnals are a little warmer and more saline for the southern leg.

Qualitatively, similar observations can be made from more recent surveys, however, there are some differences which could be significant. The surface water was much colder in 1911 than in the climatology, with zonally averaged differences of $-0.77^{\circ} \mathrm{C}$ and $-0.87^{\circ} \mathrm{C}$ for the northern and southern leg, respectively. It was also a little fresher. The comparison with the Meteor survey in the cold seasons of 1925-1926 indicates that temperature was higher in 19251926 than in 1911 in the northern part of the subtropical gyre. This warming at the surface is probably responsible for the cooling on isopycnal surfaces between 1911 and 19251926 above $\gamma=26.40$. Below that and for both legs, temperature on isopycnal surfaces increased between 1911 and 1926. This increase of $\Theta(\gamma)$ continued until the late 1950s, at least near $\gamma=26.8$. In particular for the northern leg $\left(16^{\circ} \mathrm{S}-\right.$ $24^{\circ} \mathrm{S}$ ), this results in a reduction of the slope of the $\Theta(\mathrm{S})$ diagram. This could be caused by a surface cooling or a salinity increase in the sub-Antarctic zone. On the other hand, it could be associated with a change in the water mass composition of the subtropical water. Changes in the dynamics are hard to verify with the limited data, though the thermocline along the northern section deeper in 1911 than in more recent surveys suggests that the subtropical gyre core was located farther north in 1911 than in more recent years. Altogether, the impression is that there have been large changes in the hydrography of the South Atlantic thermocline since 1911. Indeed, the SST anomalies for the South Atlantic presented by Bottomley et al. [1990] suggest that 1911 was the coldest year during the last 100 years and happened at the end of a particularly cold decade. On the other hand, at $1000 \mathrm{~m}$ in the South Atlantic subtropical gyre, close to the Antarctic intermediate waters, the average difference in temperature of the 1911 data with the compilation of Schott [1902] is less than $0.1^{\circ} \mathrm{C}$ for both legs, as is the difference between 1911 and 1925-1926 or with the Levitus [1982] climatology.
Differences at this depth near the equator have a comparable magnitude. This does not suggest large secular changes in the older Antarctic intermediate waters found at the base of the thermocline.

Obviously, a much denser coverage in time and space than is available would be necessary to understand the evolution of the hydrographic structure. The comparison of this 1911 survey with the $1925-1926$ sections is instructive in illustrating that the South Atlantic thermocline is the site of large-scale changes of the hydrographic structure of a magnitude comparable to the one in the North Atlantic subtropical gyre [Levitus, 1989]. Because there is a large inflow of South Atlantic thermocline water to the equatorial Atlantic, where it is transformed to surface water which then flows to the North Atlantic, this could also have an effect on the low-frequency fluctuations of the near-surface North Atlantic water masses. In the equatorial Atlantic the comparison of the near-equatorial Stephan data in 1911 with more recent water mass surveys does not portray very coherent changes of the central waters below 26.8 , but at shallower surfaces (up to 26.5), $\Theta(\gamma)$ is lower in 1911 compared with recent decades, similarly to the observations in the subtropical gyre. Recent surveys with a higher accuracy, as have been recently collected but not analyzed here, are required to provide an understanding of the mechanism involved in the evolution of water masses.

\section{Appendix: Hydrographic Measurements During the 1911 South Atlantic Cruises}

Because the accuracy of the 1911 data is questionable for the study of water masses, we need to thoroughly review how the data were collected. The casts were conducted with deep-sea bottles to collect water samples, and Richter reversing thermometers were mounted on them to measure in situ temperature. Surface water was collected with a bucket to estimate its temperature and salinity. The depths of the measurements were estimated from the wire length measured with a meter wheel. We will discuss successively the bottles used and how the casts were conducted, with what accuracy temperature was measured, and how salinity was estimated, as well as speculate on the error on depth estimate.

\section{Deep-Sea Bottles}

In 1911, stations were typically conducted with one or more bottles hanging from a line. Reversing thermometers were attached on a reversing frame associated with a Krümmel bottle or were attached to the reversing Ekman bottles [Ekman, 1905]. The closure (and/or reversing) was triggered either by a messenger dropped along the wire or by a propeller mechanism functioning when the wire was hauled back. During the casts of the Deutschland the two kinds of deep-sea bottles were attached to the wire, one Ekman bottle with one protected thermometer and at the end of the wire and a Krümmel bottle with a frame with one or two protected thermometers (at some stations the second protected thermometer was replaced with an unprotected thermometer). A messenger is used to close the Ekman bottle; it is not mentioned how the Krümmel bottle was closed. For the Möwe stations a single Krümmel bottle was used during each cast with a thermometer in its reversing frame and a messenger was sent to reverse the frame and close the bottle (mention is made that when a propeller closure system was used instead of the 
messenger, temperatures recorded were too high, suggesting that the thermometers would reverse in this case only after an $18 \mathrm{~m}$ uplift). An Ekman bottle was used for the Fram stations (it is possible that only one Ekman bottle was used during each cast, as was still done during some Norwegian cruises carried in 1910). Most commonly, 15 levels were sampled for each Fram station and 12 levels, at least, on the Deutschland stations. This was accomplished usually in 3 hours for a station of the Deutschland and 2 hours for a station of the Fram, which included approximately 1 hour and $40 \mathrm{~min}$, respectively, spent by the messenger falling time. The time for lowering the bottles and hauling them back on deck would probably have been at least comparable. This does not leave much time to place the bottles, retrieve them, and leave the thermometers to adjust to in situ temperature!

The Krümmel bottle is reported to have closed properly both for the Deutschland and the Möwe expeditions. On the other hand, problems were reported of nonsecured closure of the Ekman bottles (the hook would not secure the cylinder). The same problem is noted for the 1910 Michel Sars expedition in the North Atlantic [Helland-Hansen, 1926]. In those cases the salinity of the sample is very often the surface one. Many subsurface samples of the Fram expedition have surface values, which suggest the same problem. This is particularly common for samples collected deeper than $300 \mathrm{~m}$, maybe because the ship was very prone to rolling and was not easily maneuverable on station, so the wire could not be kept vertical. At the two deepest levels, 750 and $1000 \mathrm{~m}$, more than half of the water samples have surface water salinity. Because there is no mention in the titration book of whether the Ekman bottle arrived on deck closed and well secured, we cannot tell from it whether all the other data correspond to well-closed bottles.

\section{In Situ Temperature}

The protected reversing thermometers were manufactured by Richter. These round-shaped thermometers in Jena $16^{\mathrm{III}}$ glass were engraved with $1 / 10^{\circ} \mathrm{C}$ divisions. It is likely that most of these thermometers would have been for the $-2^{\circ} \mathrm{C}$ to $28^{\circ} \mathrm{C}$ range, as were some old thermometers still used during the 1925-1927 Meteor expedition. The error in reading temperature is usually a larger source of uncertainty than the uncertainty on thenull-point correction or temperaturedependent capillary error (the null-point corrections would not have evolved much in time, as illustrated by Böhnecke [1927] for the Deutschland expedition; examples of null-point corrections on Norwegian thermometers not having changed by more than $0.01^{\circ} \mathrm{C}$ over 15 years are presented in the report of the Maud 1918-1924 expedition on the Siberian shelf). It is unlikely that reading errors would exceed $0.02^{\circ} \mathrm{C}$, as discussed by Brennecke [1921]. Corrections at $0^{\circ} \mathrm{C}$ could, on the other hand, reach $0.05^{\circ} \mathrm{C}$. The question arises because the temperatures in the titration book of the Fram expedition are reported before this correction is applied (this was done later by F. Nansen, but the final data have not been found). The near homogeneity of temperature in the mixed layer, often to within $0.01^{\circ} \mathrm{C}$ for five successive levels, suggests that reading errors and thermometer-to-thermometer differences cannot have been large. On many stations, however, the $10-\mathrm{m}$ level temperature is cooler by a few $0.01^{\circ} \mathrm{C}$ than at 5 or $25 \mathrm{~m}$, but this is within the layer with a daily cycle, and we do not know in which order the different levels were measured for these stations starting in the morning.
Once the thermometers had reached the designated level, it was recommended to wait at least a few minutes before sending the messenger (during the 1901-1904 expeditions to the Norwegian Seas this time was 10 to $15 \mathrm{~min}$ ). The short duration of the Fram casts, however, suggests that the messenger was probably sent without waiting much. Presumably, this will introduce a positive bias in the temperatures of the upper ocean, in particular, just below the base of the mixed layer. Assuming that a messenger is sent immediately with a descent time of $100 \mathrm{~m} \mathrm{~min}^{-1}$ and that the thermometer has an exponential constant of $30 \mathrm{~s}$ (as found with modern thermometers, but a smaller constant is reported by Ekman [1905]), this positive bias is of the order of $0.10^{\circ} \mathrm{C}$ at $150 \mathrm{~m}$ and $0.05^{\circ} \mathrm{C}$ at $200 \mathrm{~m}$ on the northern section. Values for the southern section are less and should be much smaller farther down. There is also a random difference between the in situ temperature and the recorded temperatures, which depends on how much vertical displacement takes place during the thermometer equilibration time. Assuming a 5-m displacement due to the swells and the rolling of the vessel, this random error should not exceed $0.1-0.2^{\circ} \mathrm{C}$ in the strongest vertical temperature gradients of the thermocline.

Once on deck, the thermometers were left to equilibrate to the air temperature. An auxiliary thermometer was usually read, and the correction for the expansion of the mercury is done in order to retrieve the in situ temperature after correction for null-point errors. If the thermometers had to be reused soon after during the same station, it is likely that one could not wait long enough during the station for the equilibration. The auxiliary temperatures are reported in the Fram titration book; rather systematically at the 300-, 750-, and $1000-\mathrm{m}$ levels, they are 3 or $4^{\circ} \mathrm{C}$ lower than for the other levels. This suggests that these thermometers were not left on deck more than an hour. This could be associated with a difference of temperature between the principal and the auxiliary thermometers of the order of $1^{\circ} \mathrm{C}$, which results in an error in the in situ temperature of the order of $0.02^{\circ} \mathrm{C}$. Another uncertainty originates in that the titration book reports the readings and not the "in situ" temperatures. A formula is required to correct for the dilatation of the mercury between the in situ temperature and the temperature at which the thermometer is read. Helland-Hansen and Nansen [1909] report a few profiles for which this was done and which are colder by $0.1^{\circ} \mathrm{C}$ to $0.25^{\circ} \mathrm{C}$ at $500 \mathrm{~m}$ or deeper than in the titration book. On the basis of this scarce evidence, we apply the correction assuming a volume $v_{0}$ below scale division $0^{\circ}$ of 80 (expressed in degrees Celsius), which is in the midst of the 60-100 range indicated by Ekman [1905] (dilatation constant $K=6300$ ). For this choice, the two temperatures at $1500 \mathrm{~m}$ (2.74 and 2.83) and the three temperatures at $2000 \mathrm{~m}$ are very close to temperatures from nearby stations in 1925 [Defant, 1936]. Had we chosen $v_{0}=100$, which is also possible, the deep temperatures would have been approximately $0.05^{\circ} \mathrm{C}$ lower. This review suggests that the temperatures of the Fram cruise have errors of at least $0.05^{\circ} \mathrm{C}$ at any depth below the mixed layer.

\section{Salinity}

The water chlorinity was titrated on board during the Deutschland cruise. Brennecke [1921] compares his Deutschland titrations with the ones done after the cruise in Copenhagen and Kiel. In view of the probably long time interval which separated collection from analysis, the 
comparison is very encouraging and suggests that he could routinely achieve an accuracy of 0.02 in salinity (we convert the reported chlorinity to salinity with the ratio 1.80655 ). His deep salinities are also consistent with more recent ones. On the Möwe and the Fram, water samples were stored in bottles which were later analyzed in Hamburg (Möwe) and Bergen (Fram).

Wüst [1935] questions whether the bottles brought back from the Möwe cruise were properly closed. The problem is most serious for the bottom samples which were collected with the Sigsbee apparatus (for example, $\mathrm{S}=34.96$ reported at $3512 \mathrm{~m}$ on station 54 by $22^{\circ} 40^{\prime} \mathrm{S} / 11^{\circ} 05^{\prime} \mathrm{E}$ is certainly too high), but the scatter in $\mathrm{S}$ present at intermediate levels is also suggestive of some contamination, for example, at $600 \mathrm{~m}$ on station 55. The Möwe surface samples are also too high compared with the next subsurface level, resulting in a density inversion. The surface samples were certainly collected from a bucket; however, the effect which was some times of the order of 0.2 suggests that the buckets were not properly rinsed.

The Fram samples were analyzed between November 28 and December 18 1911, 4-6 months after collection, as was customary for the Norwegian cruises (the Michel Sars stations collected in August-September 1910 were analyzed during the following autumn and winter). If we judge from the comparison for the 1900 samples presented by HellandHansen and Nansen [1909], this should not have resulted in errors larger than 0.02 in most cases. There are too few deep samples to conclude on their accuracy by comparison with more recent cruises. During the first leg there are obviously a few samples with unrealistically high values (but not surface values), in particular, at $1000 \mathrm{~m}$. To eliminate contaminated samples, we constructed regional $\Theta-S$ scatter diagrams which we compared to the Levitus [1982] climatology and other cruises. We also investigated the presence of large density inversions. This results in removing 16 subsurface salinities and one subsurface temperature (for example, the salinity profile of station $\mathbf{5}$ is suspect). The surface Fram salinities were also collected with a bucket, and density inversions suggest that they are often too large by up to 0.10 , in which case we did replace them with the $5-\mathrm{m}$ depth salinity. Altogether, out of 888 water samples collected by the Fram, 725 salinities were retained. This still leaves a few density inversions, mostly small (of the order of $0.02 \mathrm{~kg} \mathrm{~m}^{-3}$ ). Some of them could result from the change which takes place during the 2-hour duration of a station, but some, for example, in the near-surface mixed layer of station 26 , are likely to result from errors.

Interestingly, at $750 \mathrm{~m}$, a level at which vertical displacements do not induce large errors, in particular, for the northern section, we find a salinity higher by 0.02 than in the climatology and higher by 0.03 than in the "Meteor" sections interpolated at the same latitude. It is close to 0 if taken at the same temperature, assuming a vertical displacement of the profile. The difference at $1000 \mathrm{~m}$ is of the order of 0.01 . Differences for $S$ are also very small, both at 750 and $1000 \mathrm{~m}$ for the southern section, with zonal averages less than 0.01 $( \pm 0.0290 \%$ confidence interval). This suggests that systematic errors are small. More comments on the consistency of $T$ and $S$ are provided in section 5 .

A further test on the temperature and salinity accuracy is provided by comparing nearby stations from the different cruises. In the western Atlantic, Fram stations 59 and 60 were collected within $200 \mathrm{~km}$ and 1 day of Deutschland stations 36 and 37 , respectively, a remarkable coincidence. The $\Theta-S$ diagrams (Figure A1) of these two cruises overlay neatly in this area where spatial variability of the water masses is not large in the upper $1000 \mathrm{~m}$. In the eastern Atlantic near $22^{\circ} \mathrm{S}$, Fram stations 31 and 32 are within $250 \mathrm{~km}$ of Möwstation 53. Differences are relatively large, even when excluding faulty surface samples. The Möwe salinity data are likely to be less
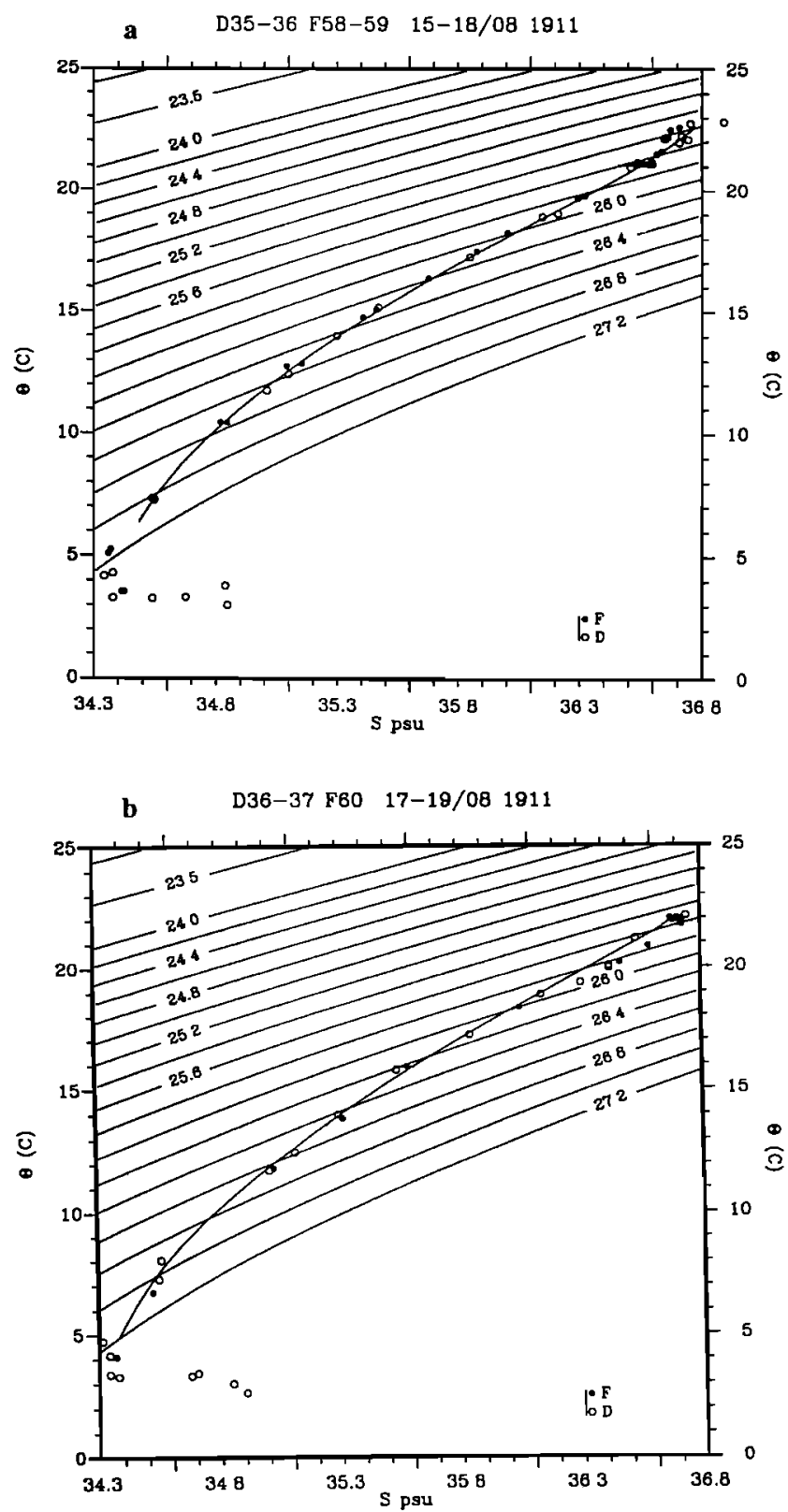

Figure A1. The $\Theta$-S diagrams for a few close by stations of the Deutschland (D) (open circles) and the Fram (F) (solid circles), (a) D35-36 and F58-59, and (b) D36-37 and F60. D35 is at $21^{\circ} 41^{\prime} \mathrm{S} / 37^{\circ} 26^{\prime} \mathrm{W}, \mathrm{D} 36$ is at $23^{\circ} 2 \mathrm{~S} / 40^{\circ} 24^{\prime} \mathrm{W}, \mathrm{D} 37$ is at $26^{\circ} 34^{\prime} \mathrm{S} / 41^{\circ} 16^{\prime} \mathrm{W}, \mathrm{F} 58$ is at $23^{\circ} 16^{\prime} \mathrm{S} / 36^{\circ} 36^{\prime} \mathrm{W}, \mathrm{F} 59$ is at $23^{\circ} 54 \mathrm{~S} / 38^{\circ} 12^{\prime} \mathrm{W}$, and $\mathrm{F} 60$ is at $24^{\circ} 39^{\prime} \mathrm{S} / 39^{\circ} 57^{\prime} \mathrm{W}$. The line is constructed by first grouping data within $0.1 \mathrm{~kg} \mathrm{~m}^{-3}$ potential density anomaly $\gamma$ classes. Within each class we have a distribution of data $(\Theta, \gamma)$ with a median potential temperature $\Theta_{i}\left(\gamma_{i}\right)$, whose standard deviation $\sigma_{i}$ is estimated assuming a Gaussian distribution. Then, for $\gamma<27.2 \mathrm{~kg} \mathrm{~m}^{-3}$, a cubic spline least squares fit is applied within $\sigma_{i}$ of the data $\Theta_{i}\left(\gamma_{i}\right)$. 
reliable than the Fram data. However, differences can also originate in the variability, both in time (2 months separate the stations) and in space. According to Stramma and Peterson's [1989] analysis of the circulation, the Fram stations are within the Benguela Current, but the closer to shore Möwe stations are within the stagnant or southward flow, with differences in salinity of at least 0.10 . From these considerations we expect that samples retained in the Fram data set are within 0.02 of the in situ salinity. There is more scatter in the comparison between closeby Deutschland and Stephan stations, suggesting a larger uncertainty in the Stephan data.

We should note that a systematic error in salinity of 0.02 can induce an enror of $0.15^{\circ} \mathrm{C}$ in $\Theta(\gamma)$ with the observed $\Theta(S)$ relationship. An error in temperature of $0.10^{\circ} \mathrm{C}$ induces an error of $0.07^{\circ} \mathrm{C}$ in $\Theta(\gamma)$. Altogether, it seems therefore that it will be the salinity error which dominates the error on the water mass analysis.

\section{Depth}

It was, of course, recommended that the ship be maneuvered to maintain the line close to the vertical. Usually, the depth was not measured but indicated by the meter wheel, which would have been calibrated. The best possible situation is the one of the Michel Sars in 1910, a highly maneuverable vessel, where deflections of the cable from the vertical did not exceed $10^{\circ}$ [Helland-Hansen, 1926], in which case one expects that the difference between depth and wire line does not exceed $10 \mathrm{~m}$ in the upper $500 \mathrm{~m}$ of the water column. Helland-Hnasen and Nansen [1912] (hereinafter referred to as HHN) report data on their plots of the Fram cruise at the depths indicated by the meter wheel which assumes a vertical cable. The reported uplifts for the Deutschland casts sometimes exceeded $60 \mathrm{~m}$ at $1000 \mathrm{~m}$, based on an unprotected thermometer placed in the frame of the Krummel bottle at the end of the line. For this cruise the wire angle was indicated, from which one can roughly estimate the actual depth [Brennecke, 1921].However, a single relationship between wire angle and uplift cannot be identified, because the conditions in which the casts were carried evolved, though, typically, a $10^{\circ}$ angle was associated with uplifts of the order of $10 \mathrm{~m}$ at $1000 \mathrm{~m}$, and the uplift increases quickly for larger angles.

The verticality of the cable is unfortunately not reported for the stations of the Möwe and the Fram. We suspect that the uplift increases with depth and hope therefore to be able to distinguish, on the sections, anomalous uplifts from the signature of anticyclonic eddies for which the vertical displacements usually decrease below the thermocline. Anomalous uplifts are clearly found at some stations of the Fram (Figure A2). This is particularly noticeable at station $\mathbf{5 5}$ $\left(22^{\circ} 29^{\prime} \mathrm{S} / 32^{\circ} \mathrm{W}\right)$ and probably also at station 54 , which present a large uplift compared to nearby stations, an unlikely occurrence according to more recent sections with comparable horizontal resolution. Actually, these stations were retained on HHN's Figure 8 of the temperature at $400 \mathrm{~m}$ : they interpreted it as the signature of an eddy. We corrected the depth estimates of eight stations (four on the northem section and four on the southern section) by a linear correction with wire length, so that final isotherm displacements in the corrected profiles relative to nearby profiles would not be larger at $1000 \mathrm{~m}$ than in the upper thermocline. These corrections of depth, which exceed $10 \%$ for five stations (and
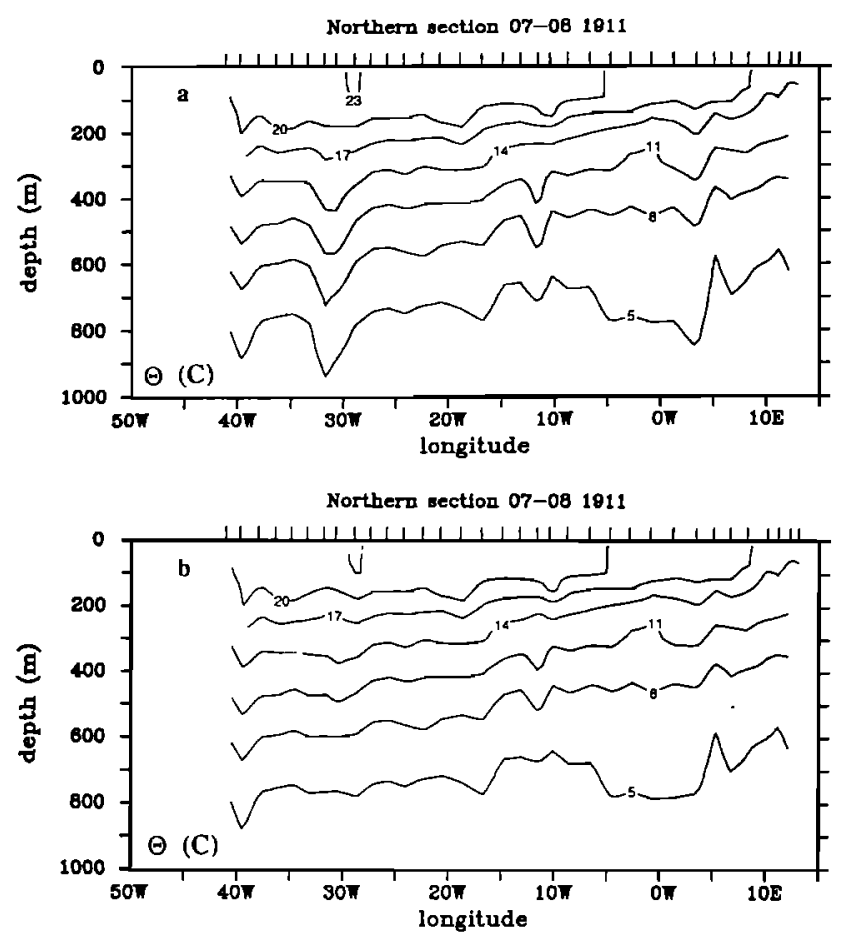

Figure A2. Potential temperature along the northern section (a) before depth corrections and (b) after depth corrections. The ticks over the upper longitude axis indicate the locations of the stations.

$18 \%$ on one, which assumes that the wire would have deviated by $25 \%$ from the vertical), greatly reduce the intensity of the variability at the station-to-station scale (Figure A2) (for the northern section, surface dynamic height relative to 1000 $\mathrm{dbar}$, the rms variations over $1^{\circ}$ of longitude diminish from 3.44 to $2.44 \mathrm{~cm}$ ).

Of course, if the wire was sometimes so tilted from the vertical, it is probable that it also happened during other stations to a lesser degree. This could have serious consequences for the interpretation of the data. For example, HHN commented that the thermocline was warmer during the Fram section than in earlier data. This warming is equivalent to a displacement of $45 \mathrm{~m}$ at $300 \mathrm{~m}$ (but less below) that could also result from a wire angle of at least $25^{\circ}$. Such a large error is not very likely if an effort was made to maintain the wire vertical.

\section{Vertical Profiles}

We want to interpret the discrete samples in the vertical as part of a continuous profile. This is not very accurate where the vertical resolution is insufficient, in particular, below $\mathbf{5 0 0}$ $\mathrm{m}$ (often more than $200 \mathrm{~m}$ separate successive samples) or in the upper thermocline at some stations. For the "Stephan" samples we group measurements collected at different sites, usually within $50 \mathrm{~km}$ of each other, that we attribute to the same station. To construct continuous profiles, we first complement missing salinities corresponding to temperature measurements, a common occurrence for "Fram". Above 700 $m$ within the central waters, we use the spline fitted $S(\Theta)$ relationship constructed from close by profiles (Figure $\mathrm{A} 1$ ). Below $700 \mathrm{~m}$ the salinity is obtained by interpolating 
linearly the salinity from the two closest stations at the longitude of the missing salinity. The $\Theta$ and $S$ Levitus [1982] seasonal climatology is interpolated by natural cubic splines to the levels of the station and is substracted from the discrete set of temperature and salinity values, resulting in a discrete set of deviations from climatology. A continuous profile of the deviations is obtained by linear interpolation, which is then recombined to the climatology to produce a higher vertical resolution profile. The mixed layer depth is estimated from a polynomial fit to three measured levels, one at a lower density and two at a higher density than the mixed layer base density. This results in a more accurate estimate than when using linear interpolation of the profile, which usually produces a smaller depth according to subsampling of recent continuous profiles. The error in estimating the mixed layer thickness usually does not exceed $10 \mathrm{~m}$ for the Fram or the Möwe stations, whose vertical sampling is of 25 or $50 \mathrm{~m}$ near the base of the mixed layer.

Acknowledgments. This research was supported by the G. Lenger Vetlesen Foundation, members of IPIECA, a grant from NODC to support data collection, and funding from NA36GP0074 and NA56GP0161. Various Norwegian institutes and Harry Dooley at ICES have provided welcomed support for locating missing stations. This work would not have been possible without the research by Odd Saelen at the Geofysisk Institutet in Bergen to locate the titration book of the Fram cruises and other information on the data. The Stephan data lists were provided by the Deusches Hydrographisches Institut and Lothar Stramma. Discussions with Deirdre Byrne and with Yochanan Kushnir have been greatly appreciated. Lamont-Doherty contribution 5422 .

\section{References}

Archer, D., S. Emerson, T. Powell, and C.S. Wong, Numerical hindcasting of sea surface $p \mathrm{CO}_{2}$ at Weather Station Papa, Prog. Oceanogr., 32, 319-351, 1994.

Barr, W., Aleksandr Stepanovich Kuchin: The Russian who went south with Amundsen, Polar Rec., 22(139), 401-412, 1985.

Böhnecke, G., Die Änderung des Nullpunktes bei TiefseeUmkippthermometern der Deutschen Atlantischen Expedition, Publ. Ser. A, 17, Veröff. Inst. für. Meereskunde zu Berlin Berlin, 1927.

Bottomley, M., C.K. Folland, J. Hsiung, R.E. Newell and D.E. Parker, Global Ocean Surface Temperature Atlas "GOSTA,", 20 pp. and 313 plates, Meteorological Office, Bracknell UK, 1990.

Brennecke, W., Die ozeanographischen Arbeiten der Deutschen Antarktischen Expedition 1911-1912, Arch. Dtsch. Seewarte, 39 (1), $1-101,1921$.

Defant, A., Stratification and circulation of the Atlantic Ocean. The troposphere, in Scientific Results of the German Atlantic Expedition of the Research Vessel Meteor 1925-27, 6(1), 289-411, Von Walter de Gruyter, Berlin, 1936.

Dickson, R.R., S.A. Malmberg, S.R. Jones, and A.J. Lee, An investigation of the earlier Great Salinity anomaly in 1910-14 in waters west of the British Isles, Rep. C.M. 1987/C:21, Int. Counc. for Exploration of the Sea, Copenhagen, 1984.

Doney, S.C., and J.L. Bullister, A chlorofluoromethan section in the eastern North Atlantic, Deep Sea Res., Part A, 39, 1857-1883, 1992.

Ekman, W., On the use of insulated water-bottles and reversing thermometers, Rapp. P.V.Cons. Int. Explor. Mer, 23, 28 p., 1905.

Ellett, D.J., Long-term water-mass changes to the west of Britain, Rep. WCP, 21, pp. 245-254, World Clim. Res. Program, Geneva, 1982.

Gordon, A.L., South Atlantic thermocline ventilation, Deep Sea Res., Part A, 36, 359-384, 1989.

Gordon, A.L. and W.F. Haxby, Agulhas eddies invade the South Atlantic: Evidence from Geosat altimeter and shipboard conductivity-temperature-depth survey, J. Geophys. Res., 95, 3117$3125,1990$.

Gordon, A.L., R.F. Weiss, W.M. Smethie, and M.J. Warner, Thermocline and intermediate water communication between the South Atlantic and Indian Oceans, J. Geophys. Res., 97, 7223-7240, 1992.
Helland-Hansen, B., Physical oceanography and meteorology, in Results of the Michel Sars North Atlantic Deep-Sea Expedition 1910, vol.I, Univ. Bergen, Bergen, 1926.

Helland-Hansen, B., and F. Nansen, The Norwegian Sea. Its physical oceanography based upon the Norwegian researches, 1900-1904, Rep. 2. Part 1 (2), 390 pp., Norw. Fish. Mar. Invest., Christiana, 1909.

Helland-Hansen, B., and F. Nansen, Remarks on the oceanographical investigations carried out by the Fram in the North Atlantic in 1910 and in the South Atlantic in 1911, in The South Pole. An Account of the Norwegian Antarctic Expedition in the Fram, 1910-1912,. by Roald Amundsen chap. 5, pp. 404-438, John Murray, London, 1912.

Hisard, P., and C. Hénin, Response of the equatorial Atlantic Ocean to the 1983-1984 wind from the Programme Français Océan et Climat dans l'Atlantique équatorial cruise data, J. Geophys. Res., 92, 3759$3768,1987$.

Jenkins, W.J., On the climate of a subtropical ocean gyre: Decade timescale variations in water mass renewal in the Sargasso Sea, $J$. Mar. Res., 40, suppl., 265-290, 1982.

Joyce, T.M., and P. Robbins, The long-term hydrographic record at Bermuda, $J$. of Clim., in press, 1996.

Krauss, W., Temperature, Salzgehalt und Dichte an der Oberfläche des Atlantischen Ozeans. Untersuchungen über die mittlere Verteilung des Salzgehaltes an der Oberfläche des Südatlantischen Ozeans un die Zonenmittelwerte der Temperatur, des Salzgehaltes un der Dichte für den gesamten Atlantischen Ozean, in Scientific Results of the German Atlantic Expedition of the Research Vessel Meteor 192527, 5(4), 412-462, Walter de Gruyter, Berlin, 1962.

Lamb, P.J., On the mixed-layer climatology of the north and tropical Atlantic, Tellus, Ser. A, 36A, 292-305, 1984.

Levitus, S., Climatological atlas of the world ocean, NOAA Prof. Pap. 13, 173 pp., U.S. Govt. Print. Off., Washington, D.C., 1982.

Levitus, S., Interpentadal variability of temperature and salinity at intermediate depths of the North Atlantic Ocean, 1970-1974 versus 1955-1959, J. Geophys. Res., 94, 6091-6131, 1989.

Maamaatuaiahutapu, K., V.C. Garçon, C. Provost, M. Boulahdid, and A.P. Osiroff, Brazil-Malvinas confluence: Water mass composition, J. Geophys. Res., 97, 9493-9505, 1992.

Mantyla, M. W., The treatment of inconsistencies in Atlantic Deep water salinity data, Deep Sea Res., Part I, 41, 1994.

McCartney, M.S., Subantarctic Mode water, in A Voyage of Discovery, George Deacon 70th Anniversary volume, edited by $M$. Angel, Deep Sea Res., suppl., 103-119, 1977.

McCartney, M.S., The subtropical recirculation of Mode waters, $J$. Mar. Res., 40, suppl.A, 427-464, 1982.

Merle, J., Atlas hydrographique saisonnier de l'Océan Atlantique tropical, Trav. Doc. ORSTOM, 82, 64 pp., 1978.

Merz, A., Eine ozeanographische Forschungsreise im Atlantischen Ozean, Verhandlungen des XVIII Deutschen Geographentages zu Innsbruck, Berlin, 82-90, 1912.

Möller, L., Methodisches zu den Vertikalschnitten längs $35.4^{\circ} \mathrm{S}$ und $30^{\circ} \mathrm{W}$ im Atlantischen, Rep. 15, Inst. für Meereskunde and der Univ. Berlin, Berlin, 1926.

Olson, D.B., G.P. Podesta, R.H. Evans, and O.B. Brown, Temporal variations in the separation of Brazil and Malvinas currents, Deep Sea Res., Part A, 35, 1971-1990, 1988.

Parker, D., and C. Folland, Worldwide surface temperature trends since the mid-19th Century, in Greenhouse-Gas-Induced Climatic Change: A Critical Appraisal of Simulations and Observations, edited by M.E. Schlesinger, pp. 173-193, Elsevier-Science, New York, 173-193, 1991.

Peterson, R.G., and L. Stramma, Upper-level circulation in the South Atlantic-Ocean, Prog. Oceanogr., 26, 1-73, 1991.

Piola, A.R., H.A. Figueroa, and A. Bianchi, Some aspects of the surface circulation south of $20^{\circ} \mathrm{S}$ revealed by first GARP global experiment drifters, J. Geophys. Res., 92, 5101-5114, 1987.

Reid, J.L., On the total geostrophic circulation of the South Atlantic Ocean: Flow patterns, tracers, and transports, Prog. Oceanogr., 23. 149-244, 1989.

Reverdin, G., R.F. Weiss, and W.J. Jenkins, Ventilation of the Atlantic Ocean equatorial thermocline, J. Geophys. Res., 98, 16,289-16,310, 1993.

Reverdin, G., D. Cayan, H.D. Dooley, D.J. Ellett, S. Levitus, Y. du Penhoat, and A. Dessier, Surface salinity of the North Atlantic: Can we reconstruct its fluctuations over the last one hundred years? Prog. Oceanogr., 33, 303-346, 1994. 
Roden, G.I., The vertical thermohaline structure in the Argentine Basin, J. Geophys. Res., 94, 877-896, 1989.

Schott, G., Ozeanographie, in Ergebnisse der Deutschen TiefseeExpedition auf dem Dampfer Valdivia 1898-1899, im Auftrag des Reichsamtes des Innern herausgegeben von Carl Chun, I, G. Fischer, Jena, 1902.

Schott, G., A. Schulz, and P. Perlewitz, Die Forschungsreise S.M.S. Möwe im Jahre 1911, Arch. Dtsch. Seewarte, 37 (1), 1914.

Smed, J., Annual and seasonal variations in the salinity of the North Atlantic surface water, Rapp. P.-V. Cons. Int. Explor. Mer, 112, 7794, 1943.

Stramma, L., The Brazil current transport south of $23^{\circ}$ S, Deep Sea Res., Part I, 36, 639-646, 1989.

Stramma, L., and R.G. Peterson, Geostrophic transport in the Benguela Current region, J. Phys. Oceanogr., 19, 1440-1448, 1989.

Stramma, L., and R.G. Peterson, The South Atlantic Current, J. Phys. Oceanogr., 20, 846-859, 1990.

Stramma, L., J. Fischer, and J. Reppin, The North Brazil Under-current, Deep Sea Res., Part I, 42, 773-796, 1995.
Tsuchiya, M., Thermostads and circulation in the upper layer of the Atlantic Ocean, Prog. Oceanogr., 16, 235-267, 1986.

Warner, M.J., and R.F. Weiss, Chlorofluoromethanes in South Atlantic Intermediate water, Deep Sea Res., Part A, 39, 2053-2075, 1992.

Wright, P., An atlas based on the 'COADS' data set: Fields of mean wind, cloudiness and humidity at the surface of the global ocean, Publ. 14, Max-Planck-Inst. für Meteorol., Hamburg, Germany, 1988.

Wiist, G., The stratosphere of the Atlantic Ocean, in Scientific Results of the German Atlantic Expedition of the Research Vessel Meteor 1925 27, 6 (1), 1-288, Von Walter de Gruyter, Berlin, 1935.

G. Reverdin, UMR 39, Groupe de Recherche de Géodésie Spatiale, 14 Avenue Edouard Belin, 31055 Toulouse, France. (e-mail: reverdin @ pontos.cnes.fr)

(Received May 8, 1995; revised October 4, 1995; accepted October 11, 1995.) 